\title{
Comparison of the effectiveness of microsatellites and SNP panels for genetic identification, traceability and assessment of parentage in an inbred Angus herd
}

\author{
María E. Fernández ${ }^{1, *}$, Daniel E. Goszczynski ${ }^{1, *}$, Juan P. Lirón ${ }^{1}$, Egle E. Villegas-Castagnasso ${ }^{1}$, \\ Mónica H. Carino ${ }^{1,2}$, María V. Ripoli ${ }^{1}$, Andrés Rogberg-Muñoz ${ }^{1}$, Diego M. Posik ${ }^{1,2}$, Pilar Peral-García ${ }^{1}$ \\ and Guillermo Giovambattista ${ }^{1}$ \\ ${ }^{1}$ Facultad de Ciencias Veterinarias, Instituto de Genética Veterinaria, Consejo Nacional de Investigaciones \\ Científicas y Técnicas, Universidad Nacional de La Plata, La Plata, Argentina. \\ ${ }^{2}$ Comisión de Investigaciones Científicas de la Provincia de Buenos Aires, La Plata, Argentina.
}

\begin{abstract}
During the last decade, microsatellites (short tandem repeats or STRs) have been successfully used for animal genetic identification, traceability and paternity, although in recent year single nucleotide polymorphisms (SNPs) have been increasingly used for this purpose. An efficient SNP identification system requires a marker set with enough power to identify individuals and their parents. Genetic diagnostics generally include the analysis of related animals. In this work, the degree of information provided by SNPs for a consanguineous herd of cattle was compared with that provided by STRs. Thirty-six closely related Angus cattle were genotyped for 18 STRs and 116 SNPs. Cumulative SNPs exclusion power values (Q) for paternity and sample matching probability (MP) yielded values greater than 0.9998 and $4.32 \mathrm{E}^{-42}$, respectively. Generally 2-3 SNPs per STR were needed to obtain an equivalent Q value. The MP showed that 24 SNPs were equivalent to the ISAG (International Society for Animal Genetics) minimal recommended set of 12 STRs $\left(M P \sim 10^{-11}\right)$. These results provide valuable genetic data that support the consensus SNP panel for bovine genetic identification developed by the Parentage Recording Working Group of ICAR (International Committee for Animal Recording).
\end{abstract}

Keywords: microsatellite, single nucleotide polymorphism, exclusion probability, genetic identification, bovine.

Received: April 9, 2012; Accepted: September 28, 2012.

\section{Introduction}

DNA markers are becoming increasingly important in animal breeding and have been successfully used in bovine identification, in parentage testing and to establish relationships between two or more individuals (GlowatzkiMullis et al., 1995; Heyen et al., 1997; Williams et al., 1997; Heaton et al., 2002). These markers have also been used to trace meat through the entire food chain (Arana et al., 2002) because of the reliable and accurate traceability they provide based on matching genetic marker profiles (Dalvit et al., 2007); the use of such markers has the potential to improve the rate of genetic progress (Van Eenennaam et al., 2007).

Microsatellites or short tandem repeats (STRs) have been the genetic markers of choice for more than two de-

Send correspondence to Guillermo Giovambattista. Facultad de Ciencias Veterinarias, Instituto de Genética Veterinaria, Consejo Nacional de Investigaciones Científicas y Técnicas, Universidad Nacional de La Plata, Calle 60 y 118 s/n, 1900 Provincia de Buenos Aires, La Plata, Argentina. E-mail: ggiovam @fcv.unlp.edu.ar.

*These authors contributed equally to this work. cades. Despite being highly polymorphic, informative and interspersed throughout the entire genome (Baumung et al., 2004; Tian et al., 2007), the results obtained with STRs by different laboratories are not always comparable because of inconsistencies in allele size calling and errors in size determination. Furthermore, STRs are time consuming for trained personnel to analyze, even with the use of appropriate software or other automated methods for allele analysis (Vignal et al., 2002). Recent advances in high-throughput DNA sequencing, computer software and bioinformatics have made the use of SNPs more popular (Heaton et al., 2002). Although in terms of genetic information a biallelic marker may be considered as a step backwards, SNPs have some promising advantages, including greater abundance (Heaton et al., 2005), genetic stability in mammals (Markovtsova et al., 2000; Nielsen, 2000; Thomson et al., 2000), simpler nomenclature and suitability to automated analysis and data interpretation (Wang et al., 1998; Lindblad-Toh et al., 2000). Furthermore, SNPs have been successfully used in the discovery of quantitative trait loci (QTL) and the association of genes with specific produc- 
tive traits (Chen and Abecasis 2007; Wollstein et al., 2007) and in the identification of individuals and breeds (Negrini et al., 2008).

A prerequisite for the development of efficient SNPbased identification systems is the description of a minimal set with sufficient power to uniquely identify individuals and their parents in a variety of popular breeds and crossbred populations (Heaton et al., 2002), even though the information content in a SNP set may vary significantly between populations (Krawczak, 1999). Previous studies designed strategies to sample the entire genetic diversity in beef cattle or purebred populations and simulated populations of purebred gene frequencies have been used to estimate the resolution and sensitivity of these methods in identifying individuals and in parental analysis (Table S7) (Heaton et al., 2002; Werner et al., 2004; López Herráez et al., 2005; Van Eenennaam et al., 2007; Baruch and Weller, 2008; Karniol et al., 2009; Allen et al., 2010; Hara et al., 2010a,b).

Most of the routine work done in livestock genetic laboratories includes the analysis of closely related animals (herdbook registry, half-sibs, etc.). Since high consanguinity is common in commercial ranches, additional markers are required to maintain the accuracy of the analysis (Pollak, 2005). In dealing with this problem, Anderson and Garza (2005) calculated the discriminatory power of SNPs in large scale parentage studies by considering the occurrence of related individuals among the members of putative mother-father-offspring trios. More recently, Fisher et al. (2009) used simulated and empirical data to evaluate the effectiveness of SNPs and STRs for parentage matching based on different degrees of relatedness.

Recently, the Parentage Recording Working Group of the ICAR (International Committee for Animal Recording) developed a cattle consensus panel of 99 SNPs, and a final ring test to certify laboratories around the world is underway. Considering this scenario, and the fact that there is considerably more experience in the use of microsatellites than SNPs (in terms of laboratory and statistical methods for analysis), the aim of this work was to compare the amount of information provided by microsatellites and SNPs within a consanguineous Angus herd.

\section{Materials and Methods}

\section{Sample and DNA extraction}

The study was done using 36 consanguineous Angus calves from a herd in Buenos Aires Province. This herd belongs to a typical commercial farm that produces, selects and sells bulls to breeding farms. The samples analyzed included half-sibs from six bulls that shared a grandfather and were obtained from the nucleus herd (consanguinity $\sim 0.2$ ). Figure S1 provides a schematic diagram of the breeding system used. DNA was extracted from blood using NucleoSpin Blood purification kits (Macherey-Nagel,
Düren, Germany), according to the manufacturer's instructions.

\section{Genotyping}

DNA genotyping was done with microsatellites and SNPs. The microsatellite markers used were $B M 1818$, BM1824, BM2113, BRR, CSRM60, CSSM66, ETH3, ETH10, ETH225, HAUT27, HEL1, INRA023, RM067, SPS115, TGLA53, TGLA122, TGLA126, and TGLA227. These 18 STRs belong to the standard FAO panel (Van de Goor et al., 2009) and/or to the standardized recommended list of the International Society for Animal Genetics (ISAG). A self-developed kit was used for PCR and the fragments were identified in an automatic MegaBACE 1000 DNA sequencer (GE Healthcare, USA). Allele sizes were standardized to the ISAG nomenclature. For SNP genotyping, 116 parentage SNPs from the Illumina BovineHD BeadChip were used (the list of SNPs is detailed in the Supplementary Material). This set comprised all SNPs included in the consensus panel for cattle identification developed by the Parentage Recording Working Group of ICAR (International Committee for Animal Recording). Genotypes with auto-calling $<85 \%$ were excluded from the analyses despite the fact that they were highly curated; 30 duplicates were included in the chip used. SNP genotyping was done using the genotyping services of GeneSeek Inc. (Lincoln, NE, USA).

\section{Statistical analysis}

Allele frequencies were determined by direct counting. ARLEQUIN 3.5 software (Schneider et al., 2000) was used to estimate the levels of genetic variability through allelic diversity $\left(\mathrm{n}_{\mathrm{a}}\right.$; total number of alleles, average number of alleles and number of alleles per locus) and the unbiased expected $\left(h_{e}\right)$ and observed heterozygosity $\left(h_{o}\right)$ for each locus and all loci. Hardy-Weinberg equilibrium (HWE) was estimated by $\mathrm{F}_{\mathrm{IS}}$ using the exact test implemented in GENEPOP 4 (Rousset and Raymond, 1997; Rousset, 2007). The $F_{I S}$ index was also used to estimate the degree of molecular consanguinity instead of pedigree consanguinity or kinship because the entire matrilineage was unavailable.

The match probability (MP) and exclusion power (Q) were estimated for cases involving two known parents, one known parent, missing parents and individual identification based on one $\left(\mathrm{Q}_{1}\right)$ and two $\left(\mathrm{Q}_{2}\right)$ marker exclusion criteria. These parameters were calculated for each marker and for the whole set as described by Weir (1996), using algorithms programmed with Visual Basic and implemented in Excel software (available upon request from the corresponding author).

\section{Results}

Thirty-six related animals were studied for 18 STRs and 116 SNPs. The animals belonged to a farm that uses artificial insemination (AI) and a natural multi-sire mating 
system. The exclusion of data with an auto-calling $<85 \%$ resulted in 4144 genotypes (32 missing data), with an average of 35.72 successful genotype (range: $34-36$ ) per locus. All of the SNPs analyzed were polymorphic $\left(\mathrm{n}_{\mathrm{a}}=2\right)$ while an STR $n_{a}$ of $5.22 \pm 1.35$ (mean \pm SD; range: 3-8) (Table 1). The minimum allele frequency (MAF) for SNPs was $>0.05$ in 114 of the 116 SNP markers, the exceptions being the SNPs ARS-USMARC-Parent-EF034087-no-rs and ARSUSMARC-Parent-AY842472-rs29001941. The SNP $h_{e}$ values ranged from 0.028 to 0.507 , with an average value of 0.417 (Table 1). For STRs, the $h_{e}$ values ranged from 0.255 to 0.816 , with an average of 0.640 (Tables S1 and S2). In total, 133 HWE tests were done (115 for SNPs and 18 for STRs), nine of which (five for SNPs and four for STRs) showed significant deviations $(p<0.05)$ from theoretical proportions (Tables S1 and S2). The allele frequencies for SNPs and STRs are available from the corresponding author upon request.

Q was estimated for each SNP marker for the most common cases of genetic identification (two known parents, one known parent, missing parents and matching samples), while MP was calculated only for matching samples (Tables S3 and S4). As shown in Figure S2, the distribution of the number of SNPs based on their individual Q values yielded a logarithmic curve. In the case of matching samples, more than $50 \%$ of the SNPs had Q values $>0.60$. When the genotypes of both parents were known, more than $50 \%$ of the SNPs had a $Q$ value $\geq 0.17$, while in the worst scenario (one known parent) this value was $\geq 0.10$. In addition, $Q$ was estimated for each whole set of markers by considering one and two mismatch criteria. The corresponding $\mathrm{Q}_{1}$ and $\mathrm{Q}_{2}$ values were $>0.999991$ and $>0.9998$ for SNPs and $>0.994$ and $>0.957$ for STRs, respectively; the MP values were $2.45 \mathrm{E}^{-42}$ and $3.0 \mathrm{E}^{-12}$ for SNPs and STRs, respectively (Table 2). Figures 1 and 2 and Tables S5 and $\mathrm{S} 6$ show the cumulative $\mathrm{Q}_{1}, \mathrm{Q}_{2}$ and $\mathrm{MP}$ values for all of the cases studied. These results show that it is necessary to
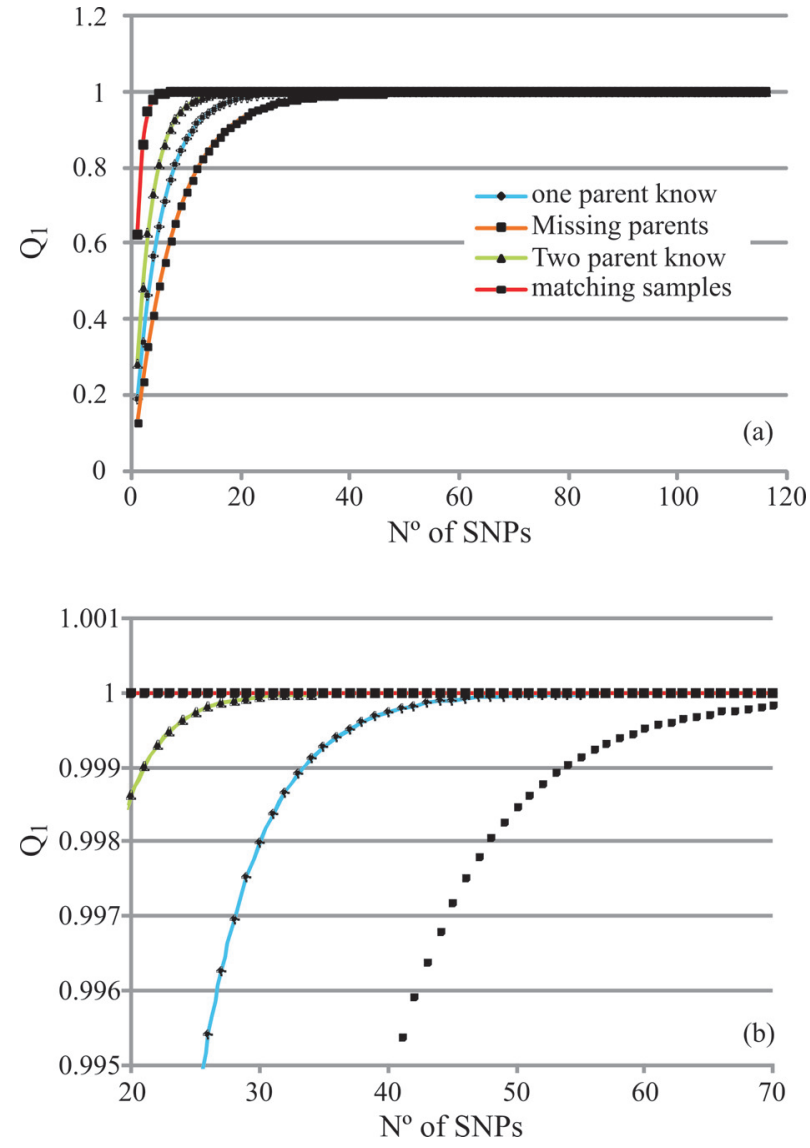

Figure 1 - Cumulative exclusion power (Q) calculated for SNPs considering $(A)$ one $\left(Q_{1}\right)$ mismatch criterion and $(B)$ two mismatch criteria $\left(Q_{2}\right)$ for cases of two known parents, one known parent, missing parents and matching samples. Markers are listed based on decreasing expected heterozygosity $\left(h_{\mathrm{e}}\right)$.

analyze between eight (matching samples scenario) and 55 (one known parent) SNPs to achieve a $\mathrm{Q}_{1} \geq 0.999$ [or cumulative non-exclusion power $\left.(1-\mathrm{Q})=1.0 \mathrm{E}^{-4}\right]$. On the other hand, for STRs, three and more than 18 markers, re-

Table 1 - Average number of alleles $\left(n_{a}\right)$, unbiased expected $\left(h_{e}\right)$, standard deviation of $n_{a}$ and $h_{e}$, range of $n_{a}$ and $h_{e}$ among loci and $F_{I S}$ estimated for the SNP and STR sets of markers in Angus inbred cattle.

\begin{tabular}{lccc}
\hline Marker type & $\mathrm{n}_{\mathrm{a}}($ range $)$ & $\mathrm{H}_{\mathrm{e}}($ range $)$ & $\mathrm{F}_{\text {IS }} \mathrm{p}$ value \\
\hline SNP & $2 \pm 0^{*}(2)$ & $0.417 \pm 0.0098(0.028-0.507)$ & $<0.001$ \\
STR & $5.22 \pm 1.35(3-8)$ & $0.640 \pm 0.015(0.255-0.816)$ & $<0.001$ \\
\hline
\end{tabular}

$*$ Mean \pm SD

Table 2 - Non-exclusion power (1 - Q) estimated for the whole set of SNPs and STRs considering one $\left(\mathrm{Q}_{1}\right)$ and two $\left(\mathrm{Q}_{2}\right)$ mismatch criteria for the cases of two known parents, one known parent, missing parents and matching samples. MP - match probability calculated for matching samples.

\begin{tabular}{|c|c|c|c|c|c|c|c|c|c|c|}
\hline \multirow[t]{2}{*}{ Locus type } & \multirow[t]{2}{*}{$\mathrm{N}$} & \multicolumn{2}{|c|}{ Both parents } & \multicolumn{2}{|c|}{ One parent } & \multicolumn{2}{|c|}{ Missing parent } & \multicolumn{2}{|c|}{ Matching samples } & \multirow[t]{2}{*}{ MP } \\
\hline & & $1-Q_{1}$ & $1-\mathrm{Q}_{2}$ & $1-Q_{1}$ & $1-Q_{2}$ & $1-Q_{1}$ & $1-Q_{2}$ & $1-Q_{1}$ & $1-\mathrm{Q}_{2}$ & \\
\hline SNPs & 116 & $1.4 \mathrm{E}-09$ & $3.2 \mathrm{E}-08$ & $1.6 \mathrm{E}-05$ & $2.1 \mathrm{E}-04$ & $4.0 \mathrm{E}-15$ & $1.6 \mathrm{E}-13$ & $<4.1 \mathrm{E}-15$ & $<4.1 \mathrm{E}-15$ & $2.4 \mathrm{E}-42$ \\
\hline STRs & 18 & $6.0 \mathrm{E}-05$ & $9.0 \mathrm{E}-04$ & $5.9 \mathrm{E}-03$ & $4.2 \mathrm{E}-02$ & $1.0 \mathrm{E}-08$ & $3.0 \mathrm{E}-06$ & $3.0 \mathrm{E}-14$ & $3.0 \mathrm{E}-12$ & $2.6 \mathrm{E}-14$ \\
\hline
\end{tabular}



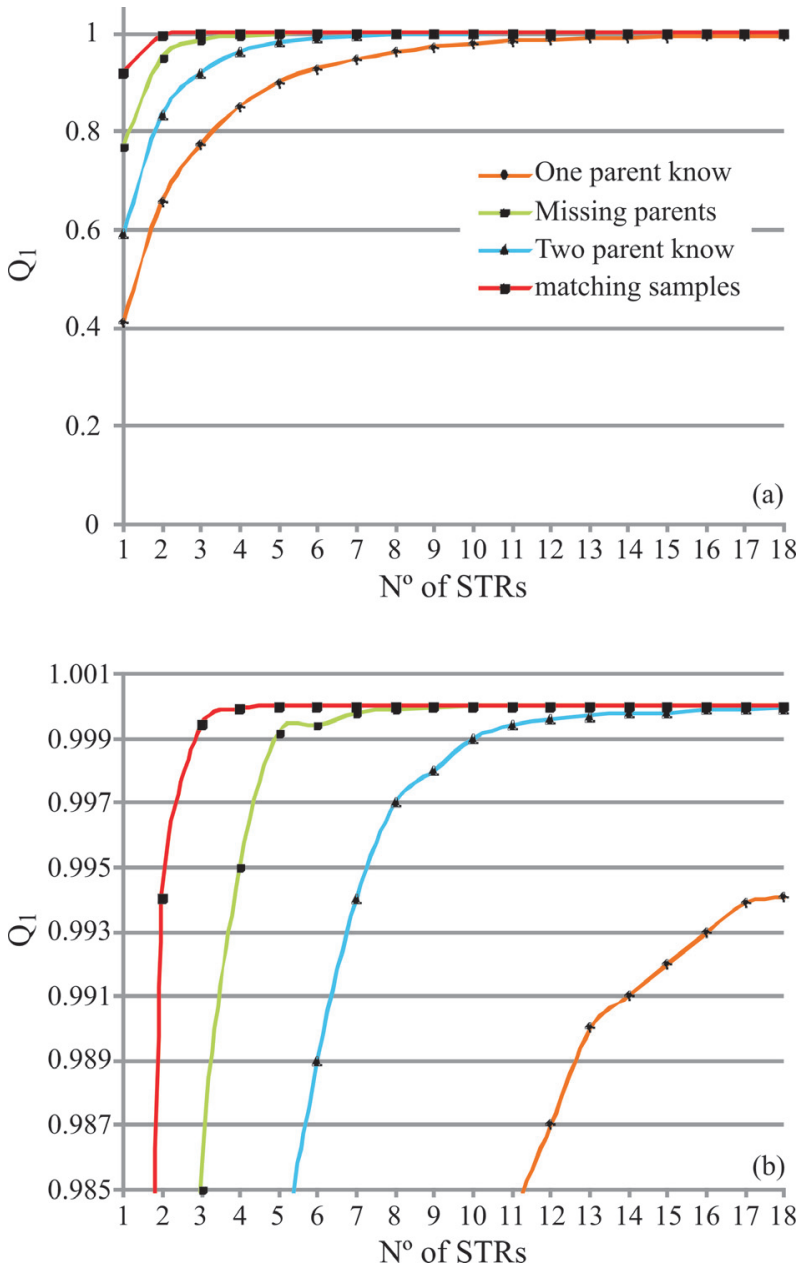

Figure 2 - Cumulative exclusion power (Q) calculated for STRs considering $(A)$ one $\left(Q_{1}\right)$ mismatch criterion and $(B)$ two mismatch criteria $\left(Q_{2}\right)$ for cases of two known parents, one known parent, missing parents and matching samples. Markers are listed based on decreasing expected heterozygosity $\left(\mathrm{h}_{\mathrm{e}}\right)$

spectively, are necessary. When using the $\mathrm{Q}_{2} \geq 0.999$ criterion, 10 (matching samples) and 79 (one known parent) SNPs are needed, whereas for STRs five and $>18$, respectively, are required. Finally, in the population studied here, 24 SNPs or 11 STRs were necessary to obtain an $\mathrm{MP} \geq 10^{-11}$.

The minimum number of markers recommended by the ISAG for bovine genetic identification is 12 STRs. In our work, around 24 SNPs were necessary to achieve an $\operatorname{MP}\left(1.78 \mathrm{E}^{-11}\right)$ equivalent to the standard marker set, and 31 SNPs $\left(M P=1.87 \mathrm{E}^{-14}\right)$ were equivalent to the $18 \mathrm{STR}$ set (Tables S5 and S6). For paternity testing, and when the two parents were known, 37 SNPs were needed for a Q value similar to the standard marker set. The resolution of more complex cases requires the use of additional markers. In these situations, such as one known parent or missing parents, around 39 and 49 SNPs are required, respectively, to obtain the same Q values as the 18 STRs (Figure 3).

\section{Discussion}

Unrelated animal sampling has been successfully used to determine breed genetic profiles in phylogeographic studies and to estimate general theoretical Q and MP values for DNA identification (traceability, parentage analysis, etc.). Several studies have evaluated and compared the Q and/or MP values obtained for STR and SNP sets (Table S7). Most of them used only representative (unrelated) purebred samples to determine the entire genetic diversity. For example, Heaton et al. (2002) analyzed three composite bovine beef groups to identify SNPs useful for animal identification and paternity testing. Werner et al. (2004) selected unrelated bulls belonging to three dairy or dual-purpose pure breeds to identify SNPs and estimate their respective allelic frequencies. López Herráez et al. (2005) genotyped Galloway animals from different farms and used STRs and SNPs to compare the Q values in the identification of individuals and parental analysis. More recently, Karniol et al. (2009) evaluated the statistical power of the 25-plex assay in traceability (identity control) and parentage testing by genotyping unrelated animals from six cattle breeds.

These common approaches do not take into account population structure and consanguinity. Furthermore, most of the routine genotyping of livestock done in genetic laboratories consists of the analysis of highly related pedigree animals rather than unrelated animals from beef breeding or dairy farms. In this framework, a marker set should have enough exclusion power to resolve any possible situation, including cases of paternity with multi-putative consanguineous sires. In view of this scenario, and considering that there is generally much more experience in the use of STRs compared with SNPs, in this work we examined the amount of information obtained with SNP and STR markers for paternity testing and genetic identification within a consanguineous commercial Angus herd.

Almost all of the SNPs examined were polymorphic, with a mean MAF of 0.328 , while more than $50 \%$ of the SNPs had a high $Q$ value because both alleles had balanced gene frequencies. These findings were not unexpected given that SNPs from the Illumina BovineHD BeadChip were validated in Angus breeds and showed a high rate of polymorphic loci $(573,437$ out of 770,000$)$. Comparison of the mean MAF values for the parentage subset of 116 SNPs showed that our inbred population gave a similar result in the Illumina test to that of the Red Angus (MAF $=0.327)$ and Angus (MAF $=0.346)$ samples used to validate the chips (ftp.illumina.com). These values ranked in the upper third distribution among 29 breeds ( $\mathrm{MAF}=0.135$ to 0.395 ), as reported by the manufacturer. The average MAF of the parentage subset was greater than those reported for the entire SNP panel (0.13-0.27), perhaps because this subset had been carefully selected and highly curated for this purpose.

The comparison of the two types of markers showed that, in the case of matching samples, two SNPs were nec- 

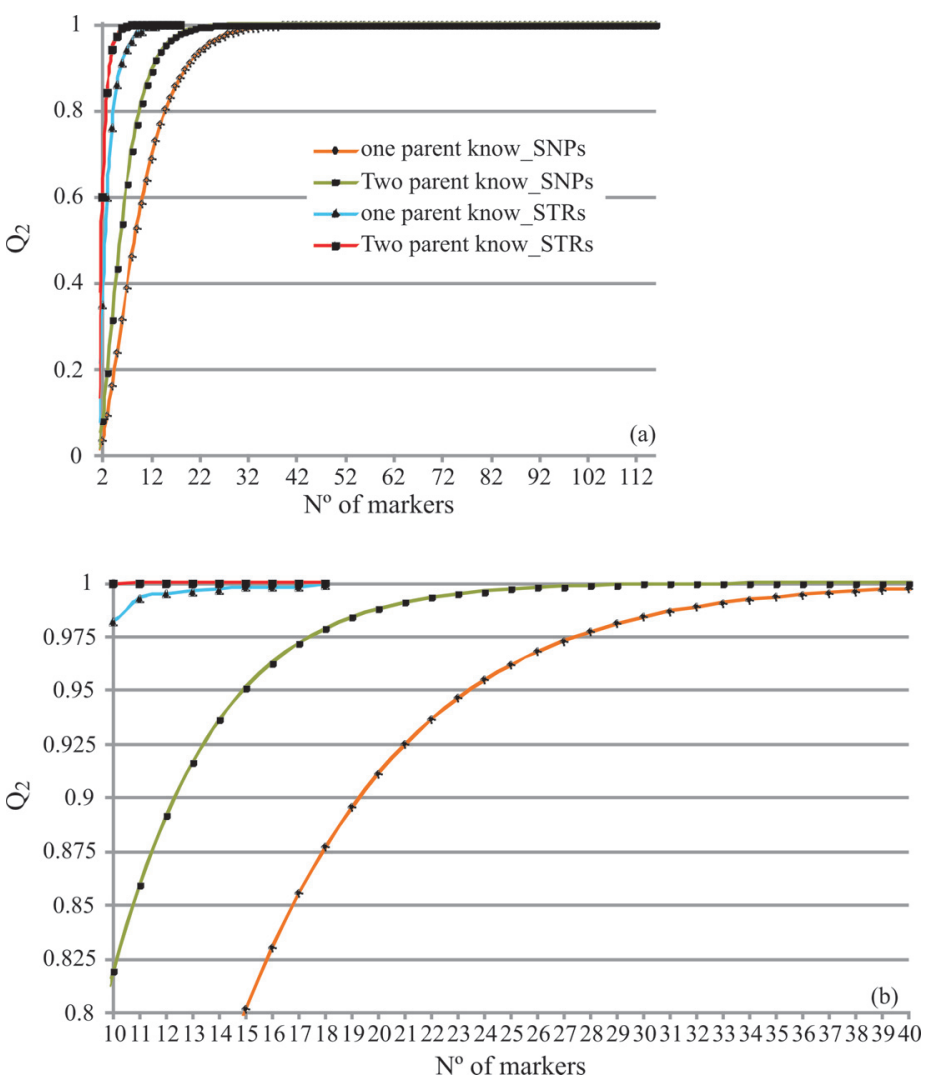

Figure 3 - Comparison of the cumulative exclusion power $(\mathrm{Q})$ curves calculated for SNPs and STRs considering two mismatch criteria $\left(\mathrm{Q}_{2}\right)$ for cases of two known parents and matching samples. Markers are listed based on decreasing expected heterozygosity $\left(\mathrm{h}_{\mathrm{e}}\right)$.

essary to provide the same statistical power as one STR (five STRs and $10 \mathrm{SNPs}$ for a $\mathrm{Q}_{2} \geq 0.999$ ). In the parentage analysis, 2.55 SNPs had a $Q$ value equivalent to one STR when both parents were known and the two exclusion $\left(\mathrm{Q}_{2}\right)$ criteria were used. In this case, 18 STRs and 46 SNPs were required to reach a $\mathrm{Q}_{2} \geq 0.999$. The $\mathrm{SNP} / \mathrm{STR}$ ratios obtained here were similar to those reported by others using unrelated animals. For example, Werner et al. (2004) observed that 37 SNPs provided the same power as a typical, commonly used microsatellite set, whereas Weller et al. (2006) reported a ratio of 2-2.25 (25 SNPs were equivalent to 11 microsatellites with five alleles) using simulated data. More recently, Fisher et al. (2009), based on an analysis of simulated data and data from a test Jersey herd, indicated that 40 SNPs (with a mean MAF of 0.35 , similar to that observed here) would be at least as effective for parentage matching as the 14 STR panel currently used for parentage testing in New Zealand dairy animals.

With regard to the MP, our results agreed with previously published data in that $25 \mathrm{SNPs}$ were equivalent to 11-12 STRs (MP $\sim 10^{-11}$ ) (Table S7), sufficient to resolve simple cases of genetic identification. However, in routine work, more markers (17-18) are usually needed to resolve complicated cases such as parentage analysis with one known parent and multiple, closely related putative sires. As shown in Table S7, an MP value of $10^{-13}$ to $10^{-15}$ can be obtained by analyzing 17-18 STRs in a purebred breed, whereas 29-34 SNPs were required to reach an equivalent MP in our inbreeding Angus population. Interestingly, by using 12 and 18 STRs we achieved MP values of $10^{-11}$ and $10^{-14}$, similar to that obtained with 24 and 31 SNPs, respectively.

Recently, Baldo et al. (2010) showed that in beef traceability $\sim 25 \%$ more microsatellite markers were needed to identify consanguineous animals $v s$. unrelated animals. In contrast, our results show that, in this same context, the number of SNPs needed to provide the same Q in consanguineous samples and in the Illumina reference samples would be similar. The difference between these two studies can be explained by the fact that biallelic SNP markers are less affected by consanguinity than multiallelic STRs. In this sense, consanguinity affects the number of alleles first and then gene diversity, thereby easily purging rare STR alleles.

In conclusion, our results show that approximately twice as many SNP markers were needed to provide the same effectiveness as STRs for genetic identification and parentage analysis in a consanguineous Angus herd. This ratio is similar to previously reported values and provides evidence that biallelic SNPs are apparently less affected by consanguinity and population structure than STRs. International collaborations by the ISAG and ICAR have sought to 
select and validate SNPs that can be used in a standard panel for genetic identification in cattle. The results described here provide genetic information that supports the consensus SNP panel developed by the Parentage Recording Working Group of ICAR.

\section{Acknowledgments}

We thank Flores Chicas de Areco for help during the experiments described here and Dr. Patricia M. Mirol for reviewing the manuscript. M.E.F. is a Fellow of Agencia Nacional de Promoción Científica y Tecnológica (ANPCyT) and D.E.G. and A.R.M. are Fellows of Consejo Nacional de Investigaciones Científicas y Técnicas (CONICET). This work was supported by ANPCyT, CONICET and Universidad Nacional de La Plata (UNLP).

\section{References}

Allen AR, Taylo M, McKeown B, Curry AI, Lavery JF, Mitchell A, Hartshorne D, Fries R and Skuce RA (2010) Compilation of a panel of informative single nucleotide polymorphisms for bovine identification in the Northern Irish cattle population. BMC Genet 11:e5.

Anderson EC and Garza JC (2005) The power of single nucleotide polymorphisms for large-scale parentage analysis. Genetics 172:2567-2582.

Arana A, Soret B, Lasa I and Alfonso L (2002) Meat traceability using DNA markers: Application to the beef industry. Meat Sci 61:367-373.

Baldo A, Rogberg-Muñoz A, Prando A, Mello Cesar AS, Lirón JP, Sorarrain N, Ramelli P, Posik DM, Pofcher E, Ripoli MV, et al. (2010) Effect of consanguinity on Argentinean Angus beef DNA traceability. Meat Sci 85:671-675.

Baruch E and Weller JI (2008) Estimation of the number of SNP genetic markers required for parentage verification. Anim Genet 39:474-479.

Baumung R, Simianer H and Hoffmann I (2004) Genetic diversity studies in farm animals - A survey. J Anim Breed Genet 121:361-373.

Chen WM and Abecasis GR (2007) Family-based association tests for genome-wide association scans. Am J Hum Genet 81:913-926.

Dalvit C, De Marchi M and Cassandro M (2007) Genetic traceability of livestock products: A review. Meat Sci 77:437449.

Fisher PJ, Malthus B, Walker MC, Corbett G and Spelman RJ (2009) The number of single nucleotide polymorphisms and on-farm data required for whole-herd parentage testing in dairy cattle herds. J Dairy Sci 92:369-374.

Glowatzki-Mullis ML, Gaillard C, Wigger G and Fries R (1995) Microsatellite-based parentage control in cattle. Anim Genet 26:7-12

Hara K, Kon Y, Sasazaki S, Mukai F and Mannen H (2010a) Development of novel SNP system for individual and pedigree control in a Japanese Black cattle population using wholegenome genotyping assay. J Anim Sci 81:6-12.

Hara K, Watabe H, Sasazaki S, Mukai F and Mannen H (2010b) Development of SNP markers for individual identification and parentage test in a Japanese black cattle population. J Anim Sci 81:152-157.

Heaton MP, Harhay GP, Bennett GL, Stone RT, Grosse WM, Casas E, Keele JW, Smith TP, Chitko-McKown CG and Laegreid WW (2002) Selection and use of SNP markers for animal identification and paternity analysis in U.S. beef cattle. Mamm Genome 13:272-281.

Heaton MP, Keen JE, Clawson ML, Harhay GP, Bauer N, Schultz C, Green BT, Durso L, Chitko-McKown CG and Laegreid WW (2005) Use of bovine single nucleotide polymorphism markers to verify sample tracking in beef processing. J Am Vet Med Assoc 226:1311-1314.

Heyen DW, Beever JE, Da Y, Evert RE, Green C, Bates SR, Ziegle JS and Lewin HA (1997) Exclusion probabilities of 22 bovine microsatellite markers in fluorescent multiplexes for semiautomated parentage testing. Anim Genet 28:21-27.

Karniol B, Shirak A, Baruch E, Singrün C, Tal A, Cahana A, Kam M, Skalski Y, Brem G, Weller JI, et al. (2009) Development of a 25-plex SNP assay for traceability in cattle. Anim Genet 40:353-356.

Krawczak M (1999) Informativity assessment for biallelic single nucleotide polymorphisms. Electrophoresis 20:1676-1681.

Lindblad-Toh K, Winchester E, Daly MJ, Wang DG, Hirschhorn JN, Laviolette JP, Ardlie K, Reich DE, Robinson E, Sklar P, et al. (2000) Large-scale discovery and genotyping of single-nucleotide polymorphisms in the mouse. Nat Genet 24:381-386.

López Herráez D, Schafer H, Mosner J, Fries HR and Wink M (2005) Comparison of microsatellite and single nucleotide polymorphism markers for the genetic analysis of a Galloway cattle population. Z Naturforsch C 60:637-643.

Markovtsova L, Marjoram P and Tavare S (2000) The age of a unique event polymorphism. Genetics 156:401-409.

Negrini R, Nicoloso L, Crepaldi P, Milanesi E, Colli L, Chegdani F, Pariset L, Dunner S, Leveziel H, Williams JL, et al. (2008) Assessing for SNP markers for assigning individuals to cattle populations. Anim Genet 40:18-26.

Nielsen R (2000) Estimation of population parameters and recombination rates from single nucleotide polymorphisms. Genetics 154:931-942.

Pollak EJ (2005) Application and impact of new genetic technologies on beef cattle breeding: A 'real world' perspective. Aust J Exp Agric 45:739-748.

Rousset F and Raymond M (1997) Statistical analyses of population genetic data: Old tools, new concepts. Trends Ecol Evol 12:313-317

Rousset F (2007) Inferences from spatial population genetics. In: Balding DJ, Bishop M and Cannings C (eds) Handbook of Statistical Genetics. 3rd edition. Wiley, Chichester, pp 945-979.

Schneider S, Roessli D and Excoffier L (2000) Arlequin: A software for population genetics data analysis. Ver. 2.0. Genetics and Biometry Lab, Department of Anthropology, University of Geneva.

Thomson R, Pritchard JK, Shen P, Oefner PJ and Feldman MW (2000) Recent common ancestry of human Y chromosomes: Evidence from DNA sequence data. Proc Natl Acad Sci USA 97:7360-7365.

Tian F, Sun D and Zhang Y (2007) Establishment of paternity testing system using microsatellites markers in Chinese Holstein. J Genet Genomics 35:279-284. 
Van de Goor LH, Panneman H and van Haeringen WA (2009) A proposal for standardization in forensic equine DNA typing: Allele nomenclature for 17 equine-specific STR loci. Anim Genet 41:122-127.

Van Eenennaam AL, Weaber RL, Drake DJ, Penedo MC, Quaas RL, Garrick DJ and Pollak EJ (2007) DNA-based paternity analysis and genetic evaluation in a large, commercial cattle ranch setting. J Anim Sci 85:3159-3169.

Vignal A, Milan D, San Cristobal M and Eggen A (2002) A review on SNP and other molecular markers and their use in animal genetics. Genet Sel Evol 43:275-305.

Wang DG, Fan JB, Siao CJ, Berno A, Young P, Sapolsky R, Ghandour G, Perkins N, Winchester E, Spencer J, et al. (1998) Large-scale identification, mapping, and genotyping of single-nucleotide polymorphisms in the human genome. Science 280:1077-1082.

Weir BS (1996) Genetic Data Analysis II: Methods for Discrete Population Genetic Data. Sinauer Associates, Sunderland, $437 \mathrm{pp}$.

Weller JI, Seroussi E and Ron M (2006) Estimation of the number of genetic markers required for individual animal identification accounting for genotyping errors. Anim Genet 37:387389.

Werner FAO, Durstewitz G, Habermann FA, Thaller G, Krämer W, Kollers S, Buitkamp J, Georges M, Brem G, Mosner J, et al. (2004) Detection and characterization of SNPs useful for identity control and parentage testing in major European dairy breeds. Anim Genet 35:44-49.

Williams JL, Usha AP, Urquhart BG and Kilroy M (1997) Verification of the identity of bovine semen using DNA microsatellite markers. Vet Rec 140:446-449.

Wollstein A, Herrmann A, Wittig M, Nothnagel M, Franke A, Nürnberg P, Schreiber S, Krawczak M and Hampe J (2007)
Efficacy assessment of SNP sets for genome-wide disease association studies. Nucleic Acids Res 35:e113.

\section{Internet Resources}

International Society for Animal Genetics, http://www.isag.org.uk (March 30, 2012).

Illumina BovineHD BeadChip,

http://www.illumina.com/Documents//prod-

ucts/datasheets/datasheet_bovineHD.pdf (March 30, 2012).

\section{Supplementary Material}

The following online material is available for this article:

- Figure S1 - Schematic diagram of the breeding system used.

- Figure S2 - Distribution of the SNP exclusion power.

- Table S1 - Alleles observed per SNP.

- Table S2 - Alleles observed per STR.

- Table S3 - Exclusion power (Q) estimated for each SNP.

- Table S4 - Exclusion power (Q) estimated for each STR.

- Table S5 - Cumulative non-exclusion power (1 - Q) calculated for SNPs.

- Table S6 - Cumulative non-exclusion power (1 - Q) calculated for STRs.

- Table S7 - Match probability values obtained in recent studies.

This material is available as part of the online article from http://www.scielo.br/gmb.

Associate Editor: Alexandre Rodrigues Caetano

License information: This is an open-access article distributed under the terms of the Creative Commons Attribution License, which permits unrestricted use, distribution, and reproduction in any medium, provided the original work is properly cited. 


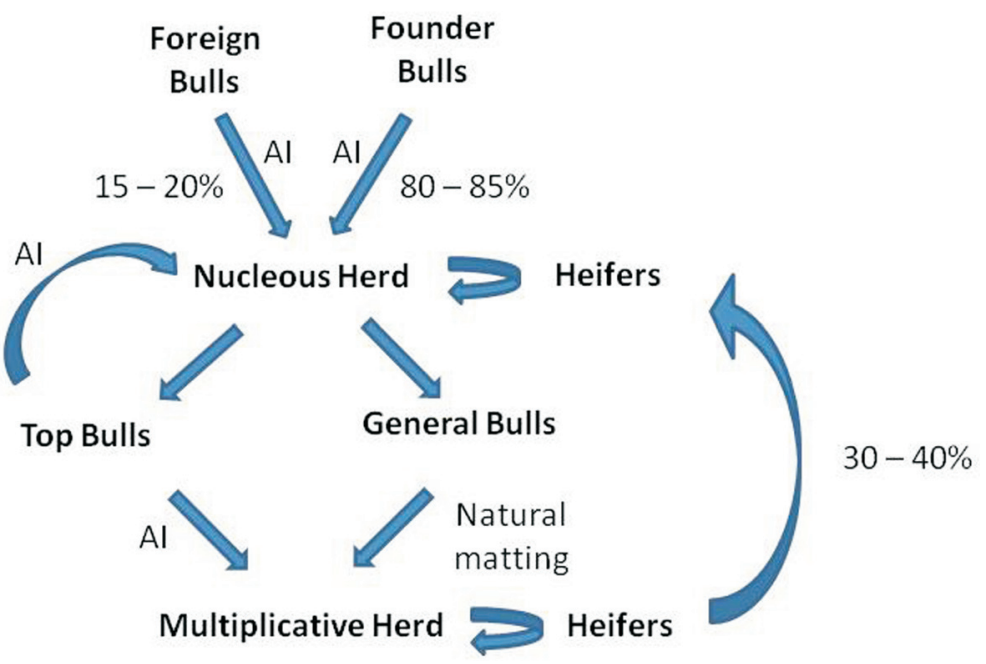

Figure S1 - Schematic diagram of the breeding system used. 
a.

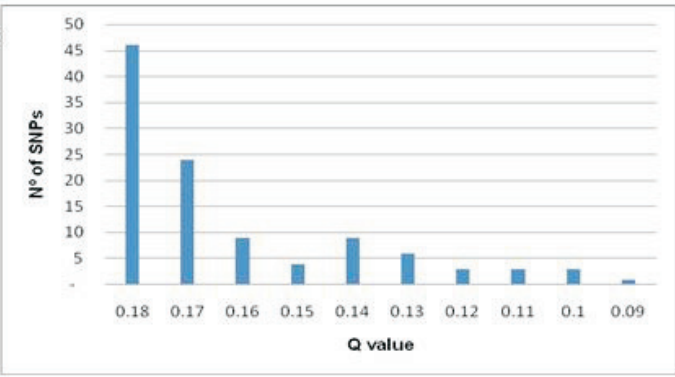

c.

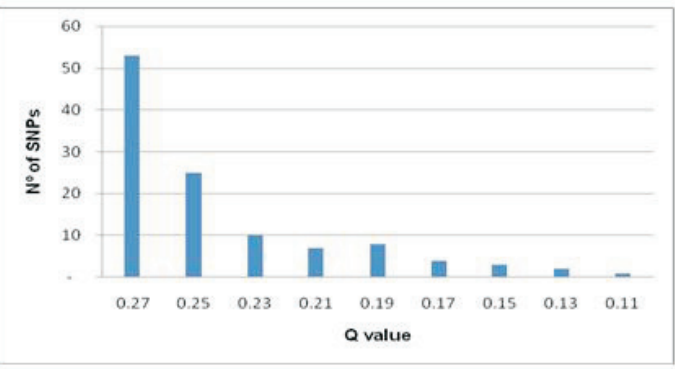

e.

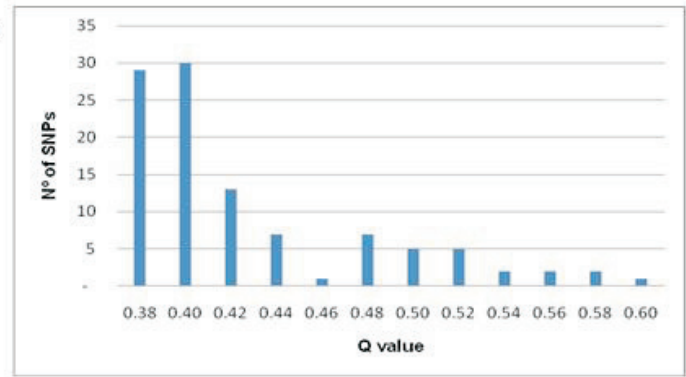

b.

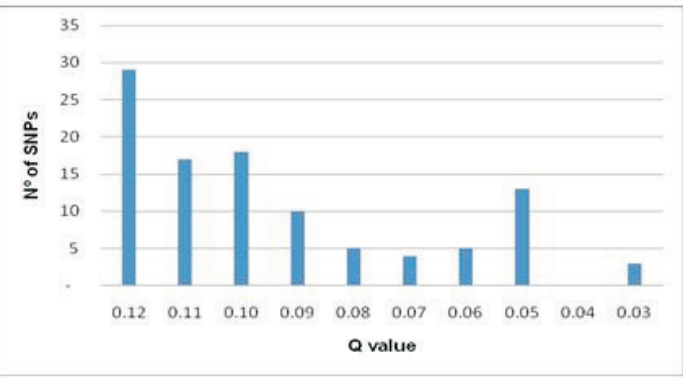

d.

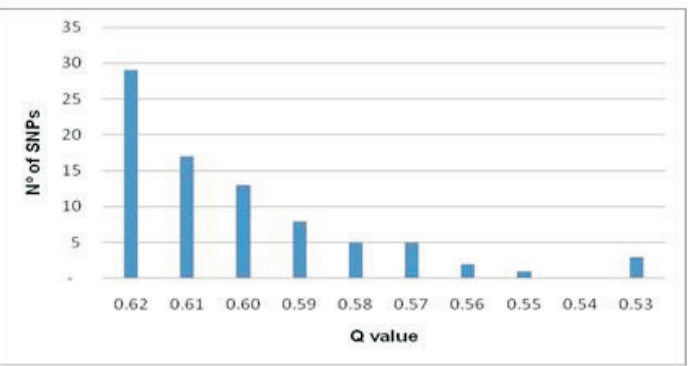

Figure S2 - Distribution of the SNP exclusion power. 
Table S1 Number of alleles observed per SNP $\left(n_{a}\right)$, heterozygosity $\left(h_{e}\right)$ estimated using ARLEQUIN 3.5, and Hardy-Weinberg equilibrium (HWE) calculated through $F_{I S}$ index and its p-value estimated using the exact test implemented in GENEPOP 4. Markers are listed in order of decreasing gene diversity $\left(h_{e}\right)$

\begin{tabular}{|c|c|c|c|c|}
\hline SNP & $\mathrm{n}_{\mathrm{a}}$ & $h_{e}$ & $F_{\text {IS }}$ & p-value \\
\hline ARS-USMARC-Parent-DQ786760-no-rs & 2 & 0.507 & -0.044 & 1.000 \\
\hline ARS-USMARC-Parent-AY857620-rs17871214 & 2 & 0.507 & 0.271 & 0.172 \\
\hline ARS-USMARC-Parent-AY914316-rs17871403 & 2 & 0.507 & -0.321 & 0.091 \\
\hline ARS-USMARC-Parent-DQ786757-rs29019900 & 2 & 0.507 & 0.456 & 0.007 \\
\hline ARS-USMARC-Parent-AY842474-rs29003226 & 2 & 0.507 & 0.069 & 0.748 \\
\hline ARS-USMARC-Parent-AY916666-no-rs & 2 & 0.507 & 0.069 & 0.748 \\
\hline ARS-USMARC-Parent-DQ404152-rs29022245 & 2 & 0.507 & -0.266 & 0.178 \\
\hline ARS-USMARC-Parent-DQ846693-rs29017621 & 2 & 0.507 & 0.069 & 0.747 \\
\hline ARS-USMARC-Parent-EF042091-rs29014974 & 2 & 0.507 & -0.154 & 0.509 \\
\hline ARS-USMARC-Parent-DQ786761-rs29012840 & 2 & 0.507 & 0.180 & 0.328 \\
\hline ARS-USMARC-Parent-DQ451555-rs29010795 & 2 & 0.505 & -0.325 & 0.090 \\
\hline ARS-USMARC-Parent-DQ489377-rs29026932 & 2 & 0.505 & -0.101 & 0.738 \\
\hline ARS-USMARC-Parent-DQ984827-rs29012019 & 2 & 0.505 & 0.233 & 0.192 \\
\hline ARS-USMARC-Parent-EF034085-rs29025677 & 2 & 0.505 & -0.101 & 0.742 \\
\hline ARS-USMARC-Parent-AY937242-rs17872223 & 2 & 0.504 & 0.175 & 0.335 \\
\hline ARS-USMARC-Parent-DQ846695-no-rs & 2 & 0.504 & -0.049 & 1.000 \\
\hline ARS-USMARC-Parent-DQ888312-rs29015945 & 2 & 0.504 & -0.161 & 0.497 \\
\hline ARS-USMARC-Parent-AY856094-rs17871190 & 2 & 0.504 & 0.208 & 0.310 \\
\hline ARS-USMARC-Parent-AY844963-rs17871338 & 2 & 0.501 & 0.002 & 1.000 \\
\hline ARS-USMARC-Parent-AY853303-no-rs & 2 & 0.501 & -0.338 & 0.087 \\
\hline ARS-USMARC-Parent-DQ846694-rs29015842 & 2 & 0.501 & 0.002 & 1.000 \\
\hline ARS-USMARC-Parent-DQ888310-rs29012422 & 2 & 0.501 & -0.224 & 0.305 \\
\hline ARS-USMARC-Parent-DQ990835-rs29012811 & 2 & 0.501 & -0.566 & 0.001 \\
\hline ARS-USMARC-Parent-EF042090-no-rs & 2 & 0.501 & -0.111 & 0.735 \\
\hline ARS-USMARC-Parent-EF150946-rs29023666 & 2 & 0.501 & 0.338 & 0.048 \\
\hline ARS-USMARC-Parent-AY851162-no-rs & 2 & 0.497 & 0.051 & 1.000 \\
\hline ARS-USMARC-Parent-AY851163-rs17871661 & 2 & 0.497 & 0.051 & 1.000 \\
\hline ARS-USMARC-Parent-AY929334-no-rs & 2 & 0.497 & -0.062 & 0.745 \\
\hline ARS-USMARC-Parent-DQ990833-rs29010147 & 2 & 0.497 & -0.062 & 0.747 \\
\hline ARS-USMARC-Parent-DQ381153-rs29012842 & 2 & 0.497 & 0.081 & 0.732 \\
\hline ARS-USMARC-Parent-DQ674265-rs29011266 & 2 & 0.497 & 0.081 & 0.733 \\
\hline ARS-USMARC-Parent-AY776154-no-rs & 2 & 0.493 & -0.015 & 1.000 \\
\hline ARS-USMARC-Parent-DQ647188-rs29011099 & 2 & 0.493 & 0.100 & 0.729 \\
\hline ARS-USMARC-Parent-DQ916058-rs29016146 & 2 & 0.493 & -0.015 & 1.000 \\
\hline ARS-USMARC-Parent-AY858890-rs29002256 & 2 & 0.493 & -0.244 & 0.182 \\
\hline ARS-USMARC-Parent-DQ500958-no-rs & 2 & 0.493 & -0.244 & 0.177 \\
\hline ARS-USMARC-Parent-DQ837645-rs29015870 & 2 & 0.493 & -0.129 & 0.507 \\
\hline ARS-USMARC-Parent-EF028073-rs29014953 & 2 & 0.492 & 0.131 & 0.493 \\
\hline ARS-USMARC-Parent-AY850194-no-rs & 2 & 0.488 & -0.083 & 0.733 \\
\hline
\end{tabular}




\begin{tabular}{|c|c|c|c|c|}
\hline RS-USMARC-Parent-DQ647190-rs290 & 2 & 0.488 & 0.033 & .000 \\
\hline RS-USMARC-Parent-EF034080-rs29024749 & 2 & 0.488 & -0.315 & 084 \\
\hline RS-USMARC-Parent-DQ846692-rs29010281 & 2 & 487 & -0.177 & 478 \\
\hline -USMARC-Parent-EF034082-rs290 & & .482 & -0.038 & 000 \\
\hline ARS-USMARC-Parent-DQ888313-no-rs & 2 & 0.482 & -0.273 & .162 \\
\hline ARS-USMARC-Parent-DQ786762-rs29010772 & & 0.481 & -0.011 & 000 \\
\hline RS-USMARC-Parent-EF093509-rs290 & & 0.481 & 0.350 & .070 \\
\hline nt-AY853302-no-rs & & .475 & -0.112 & .721 \\
\hline ARS-USMARC-Parent-DQ786763-rs29020472 & & 0.475 & 0.007 & .000 \\
\hline ARS-USMARC-Parent-EF034083-rs29018286 & & 0.475 & 0.125 & .496. \\
\hline ARS-USMARC-Parent-DQ650636-rs29024525 & & 0.474 & 0.036 & 1.000 \\
\hline -USMARC-Parent-DQ837 & & 0.474 & 0.036 & 1.000 \\
\hline ARS-USMARC-Parent-DQ839235-rs29012691 & 2 & 0.474 & 0.036 & 1.000 \\
\hline ARS-USMARC-Parent-DQ846688-rs29023691 & & 0.474 & 0.158 & 0.469 \\
\hline ARS-USMARC-Parent-AY841151-rs29003466 & & 0.468 & 0.171 & 0.472 \\
\hline ARS-USMARC-Parent-EF026 & & 0.468 & -0.312 & 0.081 \\
\hline $1-r s 29009668$ & & 0.468 & 0.171 & 0.471 \\
\hline ARS-USMARC-Par & & 0.468 & 0.051 & .000 \\
\hline ARS-USMARC-Parent-DQ789028-rs29017713 & & 0.466 & -0.168 & .461 \\
\hline ARS-USMARC-Par & & 0.466 & 0.205 & .278 \\
\hline ARS-USMARC-Par & & 0.460 & -0.398 & .025 \\
\hline ARS-USMARC-Par & & 0.460 & -0.028 & .000 \\
\hline ARS-USMARC-Parent-DQ485413-no-rs & & 0.460 & 0.095 & 0.711 \\
\hline ARS-USMARC-Par & & 0.460 & -0.028 & .000 \\
\hline ARS-USMARC-Par & & 60 & 0.339 & .062 \\
\hline RS-USMARC-Par & & 51 & 14 & 000 \\
\hline t-DQ422950-rs29012306 & & 0.451 & 0.014 & 1.000 \\
\hline ARS-USMARC-Parent-DQ786 & & 0.451 & 0.139 & 0.468 \\
\hline S-USMARC-Par & & 44 & -0.060 & 1.000 \\
\hline ARS-USMARC-Par & & & & 00 \\
\hline ARS-USMARC-Pare & L & 0.441 & 0.183 & 0.442 \\
\hline ARS-USMARC-Parent-AY943841-rs17871566 & 2 & 0.437 & -0.179 & 0.431 \\
\hline ARS-USMARC-Par & & 0.437 & -0.046 & 1.000 \\
\hline ARS-USMARC-Par & 2 & 30 & 65 & 135 \\
\hline ARS-USMARC-Pare & & 0.430 & -0.033 & 1.000 \\
\hline ARS-USMARC-Parent-DQ984825-rs29012457 & 2 & 0.426 & 0.130 & 0.450 \\
\hline ARS-USMARC-Parent-DQ786759-rs29026696 & & 0.419 & -0.264 & 0.218 \\
\hline ARS-USMARC-Parent-EF026087-rs290 & 2 & 19 & 0.140 & 0.437 \\
\hline ARS-USMARC-Parent-EF093512-rs29013546 & 2 & 0.414 & -0.246 & 0.220 \\
\hline ARS-USMARC-Parent-DQ837643-rs29018818 & & 0.407 & -0.094 & 0.693 \\
\hline ARS-USMARC-Parent-AY842475-rs29002127 & & 0.394 & 0.085 & 0.674 \\
\hline ARS-USMARC-Parent-DQ404149-no-rs & & 0.380 & -0.023 & 1.000 \\
\hline ARS-USMARC-Parent-DQ468384-rs29003967 & & 0.380 & -0.321 & 0.076 \\
\hline ARS-USMARC-Parent-DQ984826-rs29027559 & & 0.380 & 0.125 & 0.653 \\
\hline ARS-USMARC-Parent-DQ786766-rs29012070 & & 0.366 & -0.296 & 0.155 \\
\hline ARS-USMARC-Parent-DQ984828-rs29010004 & & 0.366 & 0.013 & 1.000 \\
\hline
\end{tabular}




\begin{tabular}{llllr} 
ARS-USMARC-Parent-EF034086-no-rs & 2 & 0.366 & 0.013 & 1.000 \\
ARS-USMARC-Parent-DQ786758-rs29024430 & 2 & 0.366 & -0.141 & 0.648 \\
ARS-USMARC-Parent-DQ470475-no-rs & 2 & 0.358 & -0.120 & 0.648 \\
ARS-USMARC-Parent-AY942198-rs29003010 & 2 & 0.351 & 0.050 & 1.000 \\
ARS-USMARC-Parent-DQ846689-rs29011985 & 2 & 0.351 & -0.273 & 0.160 \\
ARS-USMARC-Parent-EF026084-rs29025380 & 2 & 0.351 & 0.050 & 1.000 \\
ARS-USMARC-Parent-DQ647186-rs29014143 & 2 & 0.351 & -0.111 & 0.658 \\
ARS-USMARC-Parent-AY919868-rs29002211 & 2 & 0.335 & -0.250 & 0.303 \\
ARS-USMARC-Parent-DQ404150-rs29012530 & 2 & 0.335 & -0.081 & 1.000 \\
ARS-USMARC-Parent-DQ832700-rs29012872 & 2 & 0.335 & -0.081 & 1.000 \\
ARS-USMARC-Parent-DQ990834-rs29013727 & 2 & 0.325 & -0.057 & 1.000 \\
ARS-USMARC-Parent-EF026086-rs29013660 & 2 & 0.325 & -0.057 & 1.000 \\
ARS-USMARC-Parent-EF141102-rs29015783 & 2 & 0.318 & 0.127 & 0.587 \\
ARS-USMARC-Parent-EF093510-rs29010035 & 2 & 0.307 & -0.214 & 0.568 \\
ARS-USMARC-Parent-DQ650635-rs29012174 & 2 & 0.288 & 0.009 & 1.000 \\
ARS-USMARC-Parent-DQ866818-rs29011701 & 2 & 0.288 & -0.193 & 0.559 \\
ARS-USMARC-Parent-AY842473-rs29001956 & 2 & 0.282 & -0.186 & 0.559 \\
ARS-USMARC-Parent-DQ995977-rs29020834 & 2 & 0.282 & 0.014 & 1.000 \\
ARS-USMARC-Parent-DQ916059-rs29009907 & 2 & 0.263 & -0.167 & 0.569 \\
ARS-USMARC-Parent-DQ647187-rs29010510 & 2 & 0.243 & 0.085 & 0.514 \\
ARS-USMARC-Parent-DQ846691-rs29019814 & 2 & 0.243 & -0.148 & 1.000 \\
ARS-USMARC-Parent-AY761135-rs29003723 & 2 & 0.239 & 0.115 & 0.468 \\
ARS-USMARC-Parent-AY849380-no-rs & 2 & 0.222 & -0.129 & 1.000 \\
ARS-USMARC-Parent-DQ916057-rs29009979 & 2 & 0.200 & 0.170 & 0.354 \\
ARS-USMARC-Parent-EF164803-rs29011141 & 2 & 0.200 & -0.111 & 1.000 \\
ARS-USMARC-Parent-DQ404151-rs29019282 & 2 & 0.183 & 0.534 & 0.022 \\
ARS-USMARC-Parent-DQ647189-rs29012226 & 2 & 0.178 & -0.094 & 1.000 \\
ARS-USMARC-Parent-DQ888311-rs29017313 & 2 & 0.155 & -0.077 & 1.000 \\
ARS-USMARC-Parent-EF034084-rs29016185 & 2 & 0.131 & -0.061 & 1.000 \\
ARS-USMARC-Parent-AY842472-rs29001941 & 2 & 0.081 & -0.029 & 1.000 \\
ARS-USMARC-Parent-EF034087-no-rs & 2 & 0.028 & - & - \\
\hline & & & & \\
\hline
\end{tabular}


Table S2 Number of alleles observed per STR $\left(n_{\mathrm{a}}\right)$, heterozygosity $\left(\mathrm{h}_{\mathrm{e}}\right)$ estimated using ARLEQUIN 3.5, and Hardy-Weinberg equilibrium (HWE) calculated through $F_{I S}$ index and its $p$-value estimated using the exact test implemented in GENEPOP 4. Markers are listed in order of decreasing gene diversity $\left(h_{e}\right)$

\begin{tabular}{lcccc}
\hline \multicolumn{1}{c}{ STR } & $\mathbf{n}_{\mathbf{a}}$ & $\mathbf{h}_{\mathbf{e}}$ & $\mathbf{F}_{\mathbf{I S}}$ & $\mathbf{p}$-value \\
\hline BM1818 & 4 & 0.556 & 0.439 & $\mathbf{0 . 0 1 4}$ \\
BM1824 & 4 & 0.670 & 0.059 & 0.274 \\
ETH10 & 6 & 0.585 & -0.113 & 0.255 \\
ETH225 & 6 & 0.816 & 0.231 & $\mathbf{0 . 0 0 0 2}$ \\
ETH3 & 4 & 0.721 & -0.183 & 0.940 \\
RM067 & 6 & 0.754 & 0.711 & $\mathbf{0 . 0 0 0}$ \\
SPS115 & 5 & 0.452 & -0.108 & 0.419 \\
TGLA122 & 6 & 0.497 & 0.302 & 0.081 \\
TGLA126 & 6 & 0.768 & -0.013 & 0.784 \\
TGLA227 & 5 & 0.768 & 0.083 & 0.767 \\
BM2113 & 8 & 0.806 & 0.155 & 0.315 \\
BRR & 7 & 0.693 & -0.009 & 0.662 \\
HEL1 & 3 & 0.255 & 0.354 & $\mathbf{0 . 0 3 9}$ \\
INRA023 & 5 & 0.692 & -0.086 & 0.259 \\
CSSM66 & 3 & 0.498 & -0.106 & 1.000 \\
HAUT27 & 6 & 0.697 & -0.004 & 0.779 \\
CSRM60 & 5 & 0.591 & 0.071 & 0.380 \\
TGLA53 & 6 & 0.694 & -0.082 & 0.886 \\
\hline
\end{tabular}


Table S3. Exclusion power (Q) estimated for each SNP in the following cases: two parents known, one parent known, missing parents, and matching samples. Match probability (MP) calculated for matching samples. Markers are listed in order of decreasing $Q$ values.

\begin{tabular}{|c|c|c|c|c|c|}
\hline SNP & $\begin{array}{c}\text { two } \\
\text { parents }\end{array}$ & $\begin{array}{c}\text { one } \\
\text { parent }\end{array}$ & $\begin{array}{l}\text { Missing } \\
\text { parents }\end{array}$ & Match & MP \\
\hline ARS-USMARC-Parent-DQ786760-no-rs & 0.1875 & 0.1250 & 0.2813 & 0.6250 & 0.3750 \\
\hline ARS-USMARC-Parent-AY857620-rs17871214 & 0.1875 & 0.1250 & 0.2813 & 0.6250 & 0.3750 \\
\hline ARS-USMARC-Parent-AY914316-rs17871403 & 0.1875 & 0.1250 & 0.2813 & 0.6250 & 0.3750 \\
\hline ARS-USMARC-Parent-DQ786757-rs29019900 & 0.1875 & 0.1250 & 0.2813 & 0.6250 & 0.3750 \\
\hline ARS-USMARC-Parent-AY842474-rs29003226 & 0.1874 & 0.1248 & 0.2811 & 0.6248 & 0.3752 \\
\hline ARS-USMARC-Parent-DQ786761-rs29012840 & 0.1874 & 0.1248 & 0.2811 & 0.6248 & 0.3752 \\
\hline ARS-USMARC-Parent-DQ846693-rs29017621 & 0.1874 & 0.1248 & 0.2811 & 0.6248 & 0.3752 \\
\hline ARS-USMARC-Parent-AY916666-no-rs & 0.1874 & 0.1248 & 0.2811 & 0.6248 & 0.3752 \\
\hline ARS-USMARC-Parent-DQ404152-rs29022245 & 0.1874 & 0.1248 & 0.2811 & 0.6248 & 0.3752 \\
\hline ARS-USMARC-Parent-EF042091-rs29014974 & 0.1874 & 0.1248 & 0.2811 & 0.6248 & 0.3752 \\
\hline ARS-USMARC-Parent-DQ984827-rs29012019 & 0.1871 & 0.1242 & 0.2808 & 0.6242 & 0.3758 \\
\hline ARS-USMARC-Parent-DQ451555-rs29010795 & 0.1871 & 0.1242 & 0.2808 & 0.6242 & 0.3758 \\
\hline ARS-USMARC-Parent-DQ489377-rs29026932 & 0.1871 & 0.1242 & 0.2808 & 0.6242 & 0.3758 \\
\hline ARS-USMARC-Parent-EF034085-rs29025677 & 0.1871 & 0.1242 & 0.2808 & 0.6242 & 0.3758 \\
\hline ARS-USMARC-Parent-AY937242-rs17872223 & 0.1866 & 0.1233 & 0.2802 & 0.6232 & 0.3768 \\
\hline ARS-USMARC-Parent-DQ846695-no-rs & 0.1866 & 0.1233 & 0.2802 & 0.6232 & 0.3768 \\
\hline ARS-USMARC-Parent-DQ888312-rs29015945 & 0.1866 & 0.1233 & 0.2802 & 0.6232 & 0.3768 \\
\hline ARS-USMARC-Parent-AY856094-rs17871190 & 0.1866 & 0.1232 & 0.2801 & 0.6231 & 0.3769 \\
\hline ARS-USMARC-Parent-AY853303-no-rs & 0.1859 & 0.1219 & 0.2793 & 0.6219 & 0.3781 \\
\hline ARS-USMARC-Parent-DQ888310-rs29012422 & 0.1859 & 0.1219 & 0.2793 & 0.6219 & 0.3781 \\
\hline ARS-USMARC-Parent-EF042090-no-rs & 0.1859 & 0.1219 & 0.2793 & 0.6219 & 0.3781 \\
\hline ARS-USMARC-Parent-AY844963-rs17871338 & 0.1859 & 0.1219 & 0.2793 & 0.6219 & 0.3781 \\
\hline ARS-USMARC-Parent-DQ846694-rs29015842 & 0.1859 & 0.1219 & 0.2793 & 0.6219 & 0.3781 \\
\hline ARS-USMARC-Parent-DQ990835-rs29012811 & 0.1859 & 0.1219 & 0.2793 & 0.6219 & 0.3781 \\
\hline ARS-USMARC-Parent-EF150946-rs29023666 & 0.1859 & 0.1219 & 0.2793 & 0.6219 & 0.3781 \\
\hline ARS-USMARC-Parent-AY851163-rs17871661 & 0.1851 & 0.1202 & 0.2782 & 0.6200 & 0.3800 \\
\hline ARS-USMARC-Parent-AY929334-no-rs & 0.1851 & 0.1202 & 0.2782 & 0.6200 & 0.3800 \\
\hline ARS-USMARC-Parent-DQ990833-rs29010147 & 0.1851 & 0.1202 & 0.2782 & 0.6200 & 0.3800 \\
\hline ARS-USMARC-Parent-AY851162-no-rs & 0.1851 & 0.1202 & 0.2782 & 0.6200 & 0.3800 \\
\hline ARS-USMARC-Parent-DQ381153-rs29012842 & 0.1849 & 0.1200 & 0.2780 & 0.6197 & 0.3803 \\
\hline ARS-USMARC-Parent-DQ674265-rs29011266 & 0.1849 & 0.1200 & 0.2780 & 0.6197 & 0.3803 \\
\hline ARS-USMARC-Parent-AY776154-no-rs & 0.1840 & 0.1182 & 0.2769 & 0.6178 & 0.3822 \\
\hline ARS-USMARC-Parent-AY858890-rs29002256 & 0.1840 & 0.1182 & 0.2769 & 0.6178 & 0.3822 \\
\hline ARS-USMARC-Parent-DQ500958-no-rs & 0.1840 & 0.1182 & 0.2769 & 0.6178 & 0.3822 \\
\hline ARS-USMARC-Parent-DQ647188-rs29011099 & 0.1840 & 0.1182 & 0.2769 & 0.6178 & 0.3822 \\
\hline ARS-USMARC-Parent-DQ837645-rs29015870 & 0.1840 & 0.1182 & 0.2769 & 0.6178 & 0.3822 \\
\hline ARS-USMARC-Parent-DQ916058-rs29016146 & 0.1840 & 0.1182 & 0.2769 & 0.6178 & 0.3822 \\
\hline ARS-USMARC-Parent-EF028073-rs29014953 & 0.1838 & 0.1178 & 0.2766 & 0.6173 & 0.3827 \\
\hline
\end{tabular}


ARS-USMARC-Parent-DQ647190-rs29013632 ARS-USMARC-Parent-AY850194-no-rs

ARS-USMARC-Parent-EF034080-rs29024749

ARS-USMARC-Parent-DQ846692-rs29010281

ARS-USMARC-Parent-DQ888313-no-rs

ARS-USMARC-Parent-EF034082-rs29013532

ARS-USMARC-Parent-DQ786762-rs29010772

ARS-USMARC-Parent-EF093509-rs29015170

ARS-USMARC-Parent-AY853302-no-rs

ARS-USMARC-Parent-DQ786763-rs29020472

ARS-USMARC-Parent-EF034083-rs29018286

ARS-USMARC-Parent-DQ650636-rs29024525

ARS-USMARC-Parent-DQ839235-rs29012691

ARS-USMARC-Parent-DQ846688-rs29023691

ARS-USMARC-Parent-DQ837644-rs29010468

ARS-USMARC-Parent-DQ404153-no-rs

ARS-USMARC-Parent-EF026085-rs29021607

ARS-USMARC-Parent-AY841151-rs29003466

ARS-USMARC-Parent-EF034081-rs29009668

ARS-USMARC-Parent-DQ789028-rs29017713

ARS-USMARC-Parent-EF089234-rs29020870

ARS-USMARC-Parent-DQ422949-rs29011466

ARS-USMARC-Parent-DQ485413-no-rs

ARS-USMARC-Parent-DQ435443-rs29010802

ARS-USMARC-Parent-DQ846690-no-rs

ARS-USMARC-Parent-DQ888309-rs29013741

ARS-USMARC-Parent-AY941204-rs17872131

ARS-USMARC-Parent-DQ422950-rs29012306

ARS-USMARC-Parent-DQ786765-rs29009858

ARS-USMARC-Parent-EF093511-rs29012316

ARS-USMARC-Parent-DQ866817-no-rs

ARS-USMARC-Parent-DQ990832-rs29015065

ARS-USMARC-Parent-AY943841-rs17871566

ARS-USMARC-Parent-DQ837646-rs29012894

ARS-USMARC-Parent-AY939849-rs17870274

ARS-USMARC-Parent-DQ995976-no-rs

ARS-USMARC-Parent-DQ984825-rs29012457

ARS-USMARC-Parent-DQ786759-rs29026696

ARS-USMARC-Parent-EF026087-rs29011643

ARS-USMARC-Parent-EF093512-rs29013546

ARS-USMARC-Parent-DQ837643-rs29018818

ARS-USMARC-Parent-AY842475-rs29002127

ARS-USMARC-Parent-DQ468384-rs29003967

ARS-USMARC-Parent-DQ984826-rs29027559

ARS-USMARC-Parent-DQ404149-no-rs

ARS-USMARC-Parent-DQ786758-rs29024430

$\begin{array}{lllll}0.1827 & 0.1157 & 0.2753 & 0.6150 & 0.3850 \\ 0.1827 & 0.1157 & 0.2753 & 0.6150 & 0.3850 \\ 0.1827 & 0.1157 & 0.2753 & 0.6150 & 0.3850 \\ 0.1824 & 0.1152 & 0.2749 & 0.6144 & 0.3856 \\ 0.1812 & 0.1130 & 0.2734 & 0.6117 & 0.3883 \\ 0.1812 & 0.1130 & 0.2734 & 0.6117 & 0.3883 \\ 0.1808 & 0.1123 & 0.2730 & 0.6109 & 0.3891 \\ 0.1808 & 0.1123 & 0.2730 & 0.6109 & 0.3891 \\ 0.1794 & 0.1099 & 0.2713 & 0.6079 & 0.3921 \\ 0.1794 & 0.1099 & 0.2713 & 0.6079 & 0.3921 \\ 0.1794 & 0.1099 & 0.2713 & 0.6079 & 0.3921 \\ 0.1790 & 0.1090 & 0.2708 & 0.6068 & 0.3932 \\ 0.1790 & 0.1090 & 0.2708 & 0.6068 & 0.3932 \\ 0.1790 & 0.1090 & 0.2708 & 0.6068 & 0.3932 \\ 0.1790 & 0.1090 & 0.2708 & 0.6068 & 0.3932 \\ 0.1775 & 0.1065 & 0.2690 & 0.6035 & 0.3965 \\ 0.1775 & 0.1065 & 0.2690 & 0.6035 & 0.3965 \\ 0.1775 & 0.1065 & 0.2690 & 0.6035 & 0.3965 \\ 0.1775 & 0.1065 & 0.2690 & 0.6035 & 0.3965 \\ 0.1769 & 0.1054 & 0.2682 & 0.6021 & 0.3979 \\ 0.1769 & 0.1054 & 0.2682 & 0.6021 & 0.3979 \\ 0.1753 & 0.1027 & 0.2663 & 0.5984 & 0.4016 \\ 0.1753 & 0.1027 & 0.2663 & 0.5984 & 0.4016 \\ 0.1753 & 0.1027 & 0.2663 & 0.5984 & 0.4016 \\ 0.1753 & 0.1027 & 0.2663 & 0.5984 & 0.4016 \\ 0.1753 & 0.1027 & 0.2663 & 0.5984 & 0.4016 \\ 0.1728 & 0.0988 & 0.2634 & 0.5926 & 0.4074 \\ 0.1728 & 0.0988 & 0.2634 & 0.5926 & 0.4074 \\ 0.1728 & 0.0988 & 0.2634 & 0.5926 & 0.4074 \\ 0.1710 & 0.0958 & 0.2611 & 0.5880 & 0.4120 \\ 0.1701 & 0.0945 & 0.2601 & 0.5860 & 0.4140 \\ 0.1701 & 0.0945 & 0.2601 & 0.5860 & 0.4140 \\ 0.1691 & 0.0929 & 0.2589 & 0.5834 & 0.4166 \\ 0.1691 & 0.0929 & 0.2589 & 0.5834 & 0.4166 \\ 0.1672 & 0.0901 & 0.2566 & 0.5786 & 0.4214 \\ 0.1672 & 0.0901 & 0.2566 & 0.5786 & 0.4214 \\ 0.1659 & 0.0882 & 0.2551 & 0.5754 & 0.4246 \\ 0.1639 & 0.0854 & 0.2527 & 0.5703 & 0.4297 \\ 0.1639 & 0.0854 & 0.2527 & 0.5703 & 0.4297 \\ 0.1624 & 0.0833 & 0.2509 & 0.5664 & 0.4336 \\ 0.1604 & 0.0805 & 0.2484 & 0.5610 & 0.4390 \\ 0.1523 & 0.0755 & 0.2438 & 0.5506 & 0.4494 \\ 0.073 & 0.2388 & 0.5391 & 0.4609 \\ 0.0651 & 0.2333 & 0.5263 & 0.4737\end{array}$




\begin{tabular}{|c|c|c|c|c|c|}
\hline ARS-USMARC-Parent-DQ786766-rs29012070 & 0.1478 & 0.0651 & 0.2333 & 0.5263 & 0.4737 \\
\hline ARS-USMARC-Parent-DQ984828-rs29010004 & 0.1478 & 0.0651 & 0.2333 & 0.5263 & 0.4737 \\
\hline ARS-USMARC-Parent-EF034086-no-rs & 0.1478 & 0.0651 & 0.2333 & 0.5263 & 0.4737 \\
\hline ARS-USMARC-Parent-DQ470475-no-rs & 0.1452 & 0.0622 & 0.2301 & 0.5188 & 0.4812 \\
\hline ARS-USMARC-Parent-DQ647186-rs29014143 & 0.1430 & 0.0597 & 0.2273 & 0.5121 & 0.4879 \\
\hline ARS-USMARC-Parent-AY942198-rs29003010 & 0.1430 & 0.0597 & 0.2273 & 0.5121 & 0.4879 \\
\hline ARS-USMARC-Parent-DQ846689-rs29011985 & 0.1430 & 0.0597 & 0.2273 & 0.5121 & 0.4879 \\
\hline ARS-USMARC-Parent-EF026084-rs29025380 & 0.1430 & 0.0597 & 0.2273 & 0.5121 & 0.4879 \\
\hline ARS-USMARC-Parent-DQ832700-rs29012872 & 0.1377 & 0.0544 & 0.2208 & 0.4965 & 0.5035 \\
\hline ARS-USMARC-Parent-AY919868-rs29002211 & 0.1377 & 0.0544 & 0.2208 & 0.4965 & 0.5035 \\
\hline ARS-USMARC-Parent-DQ404150-rs29012530 & 0.1377 & 0.0544 & 0.2208 & 0.4965 & 0.5035 \\
\hline ARS-USMARC-Parent-DQ990834-rs29013727 & 0.1344 & 0.0512 & 0.2166 & 0.4864 & 0.5136 \\
\hline ARS-USMARC-Parent-EF026086-rs29013660 & 0.1344 & 0.0512 & 0.2166 & 0.4864 & 0.5136 \\
\hline ARS-USMARC-Parent-EF141102-rs29015783 & 0.1321 & 0.0491 & 0.2137 & 0.4793 & 0.5207 \\
\hline ARS-USMARC-Parent-EF093510-rs29010035 & 0.1284 & 0.0457 & 0.2089 & 0.4677 & 0.5323 \\
\hline ARS-USMARC-Parent-DQ650635-rs29012174 & 0.1219 & 0.0404 & 0.2004 & 0.4471 & 0.5529 \\
\hline ARS-USMARC-Parent-DQ866818-rs29011701 & 0.1219 & 0.0404 & 0.2004 & 0.4471 & 0.5529 \\
\hline ARS-USMARC-Parent-AY842473-rs29001956 & 0.1196 & 0.0386 & 0.1974 & 0.4398 & 0.5602 \\
\hline ARS-USMARC-Parent-DQ995977-rs29020834 & 0.1196 & 0.0386 & 0.1974 & 0.4398 & 0.5602 \\
\hline ARS-USMARC-Parent-DQ916059-rs29009907 & 0.1127 & 0.0335 & 0.1881 & 0.4172 & 0.5828 \\
\hline ARS-USMARC-Parent-DQ647187-rs29010510 & 0.1053 & 0.0286 & 0.1779 & 0.3926 & 0.6074 \\
\hline ARS-USMARC-Parent-DQ846691-rs29019814 & 0.1053 & 0.0286 & 0.1779 & 0.3926 & 0.6074 \\
\hline ARS-USMARC-Parent-AY761135-rs29003723 & 0.1039 & 0.0277 & 0.1760 & 0.3879 & 0.6121 \\
\hline ARS-USMARC-Parent-AY849380-no-rs & 0.0974 & 0.0239 & 0.1668 & 0.3657 & 0.6343 \\
\hline ARS-USMARC-Parent-DQ916057-rs29009979 & 0.0890 & 0.0195 & 0.1545 & 0.3365 & 0.6635 \\
\hline ARS-USMARC-Parent-EF164803-rs29011141 & 0.0890 & 0.0195 & 0.1545 & 0.3365 & 0.6635 \\
\hline ARS-USMARC-Parent-DQ404151-rs29019282 & 0.0819 & 0.0162 & 0.1439 & 0.3114 & 0.6886 \\
\hline ARS-USMARC-Parent-DQ647189-rs29012226 & 0.0801 & 0.0154 & 0.1411 & 0.3049 & 0.6951 \\
\hline ARS-USMARC-Parent-DQ888311-rs29017313 & 0.0706 & 0.0117 & 0.1263 & 0.2705 & 0.7295 \\
\hline ARS-USMARC-Parent-EF034084-rs29016185 & 0.0604 & 0.0084 & 0.1100 & 0.2334 & 0.7666 \\
\hline ARS-USMARC-Parent-AY842472-rs29001941 & 0.0383 & 0.0032 & 0.0723 & 0.1502 & 0.8498 \\
\hline ARS-USMARC-Parent-EF034087-no-rs & 0.0135 & 0.0004 & 0.0265 & 0.0537 & 0.9463 \\
\hline
\end{tabular}


Table S4 Exclusion power (Q) estimated for each STR in the following cases: two parents known, one parent known, missing parents and matching samples. Match probability (MP) calculated for matching samples. Markers are listed in order of decreasing $Q$ values

\begin{tabular}{cccccc}
\hline Locus & two parents & one parent & $\begin{array}{c}\text { Missing } \\
\text { parents }\end{array}$ & Match & MP \\
\hline ETH225 & 0.5941 & 0.4152 & 0.7745 & 0.9270 & 0.0730 \\
BM2113 & 0.5893 & 0.4103 & 0.7757 & 0.9245 & 0.0755 \\
TGLA227 & 0.5182 & 0.3405 & 0.7022 & 0.8944 & 0.1056 \\
TGLA126 & 0.5175 & 0.3408 & 0.7002 & 0.8941 & 0.1059 \\
RM067 & 0.5050 & 0.3283 & 0.6915 & 0.8871 & 0.1129 \\
BRR & 0.4720 & 0.2851 & 0.6789 & 0.8670 & 0.1330 \\
ETH3 & 0.4537 & 0.2811 & 0.6310 & 0.8624 & 0.1376 \\
HAUT27 & 0.4453 & 0.2726 & 0.6342 & 0.8520 & 0.1480 \\
TGLA53 & 0.4395 & 0.2681 & 0.6264 & 0.8489 & 0.1511 \\
INRA023 & 0.4273 & 0.2614 & 0.6088 & 0.8410 & 0.1590 \\
BM1824 & 0.4004 & 0.2347 & 0.5768 & 0.8260 & 0.1740 \\
ETH10 & 0.3637 & 0.1882 & 0.5587 & 0.7856 & 0.2144 \\
CSRM60 & 0.3419 & 0.1814 & 0.5180 & 0.7731 & 0.2269 \\
BM1818 & 0.3048 & 0.1524 & 0.4672 & 0.7405 & 0.2595 \\
TGLA122 & 0.2954 & 0.1314 & 0.4767 & 0.7099 & 0.3603 \\
SPS115 & 0.2423 & 0.1006 & 0.3929 & 0.6525 & 0.3475 \\
CSSM66 & 0.2074 & 0.1182 & 0.3165 & 0.6397 & 0.3603 \\
HEL1 & 0.1272 & 0.0309 & 0.2249 & 0.4203 & 0.5797 \\
\hline
\end{tabular}




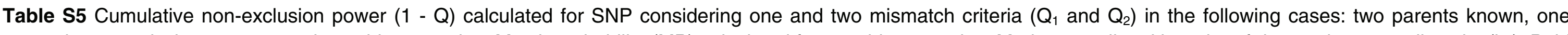

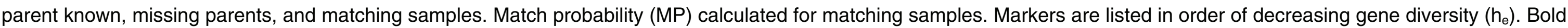
underlined when cumulative $1-Q$ reach to $1.0 \mathrm{E}-4(Q=0.999)$

\begin{tabular}{|c|c|c|c|c|c|c|c|c|c|c|}
\hline \multirow[b]{2}{*}{ Locus № } & \multirow[b]{2}{*}{ SNP } & \multicolumn{2}{|c|}{ two parents } & \multicolumn{2}{|c|}{ one parent } & \multicolumn{2}{|c|}{ Missing parents } & \multicolumn{2}{|c|}{ Match } & \multirow[b]{2}{*}{ MP } \\
\hline & & $1-Q_{1}$ & $1-Q_{2}$ & $1-Q_{1}$ & $1-Q_{2}$ & $1-Q_{1}$ & $1-Q_{2}$ & $1-Q_{1}$ & $1-Q_{2}$ & \\
\hline 1 & DQ786760 & 0.812 & - & 0.875 & - & 0.719 & - & 0.375 & - & 3.750E-01 \\
\hline 2 & AY857620 & 6.6E-01 & $9.6 \mathrm{E}-01$ & 7.7E-01 & $9.8 \mathrm{E}-01$ & 5.2E-01 & $9.2 \mathrm{E}-01$ & 1.4E-01 & 6.1E-01 & $1.406 \mathrm{E}-01$ \\
\hline 3 & AY914316 & 5.4E-01 & $9.1 \mathrm{E}-01$ & 6.7E-01 & $9.6 \mathrm{E}-01$ & 3.7E-01 & 8.1E-01 & 5.3E-02 & 3.2E-01 & 5.273E-02 \\
\hline 4 & DQ786757 & 4.4E-01 & 8.4E-01 & 5.9E-01 & $9.2 \mathrm{E}-01$ & 2.7E-01 & $6.8 \mathrm{E}-01$ & 2.0E-02 & 1.5E-01 & 1.978E-02 \\
\hline 5 & AY842474 & 3.5E-01 & 7.6E-01 & 5.1E-01 & 8.8E-01 & 1.9E-01 & 5.7E-01 & 7.4E-03 & 6.9E-02 & 7.420E-03 \\
\hline 6 & DQ786761 & 2.9E-01 & 6.9E-01 & 4.5E-01 & 8.3E-01 & 1.4E-01 & 4.6E-01 & 2.8E-03 & 3.1E-02 & $2.784 \mathrm{E}-03$ \\
\hline 7 & DQ846693 & 2.3E-01 & 6.1E-01 & 3.9E-01 & 7.9E-01 & 9.9E-02 & 3.7E-01 & 1.0E-03 & 1.3E-02 & $1.044 \mathrm{E}-03$ \\
\hline 8 & AY916666 & 1.9E-01 & 5.4E-01 & 3.4E-01 & 7.4E-01 & 7.1E-02 & 2.9E-01 & 3.9E-04 & 5.6E-03 & 3.919E-04 \\
\hline 9 & DQ404152 & $1.5 \mathrm{E}-01$ & 4.7E-01 & 3.0E-01 & 6.9E-01 & 5.1E-02 & 2.3E-01 & $1.5 \mathrm{E}-04$ & 2.4E-03 & 1.470E-04 \\
\hline 10 & EF042091 & 1.3E-01 & 4.1E-01 & 2.6E-01 & 6.4E-01 & 3.7E-02 & 1.8E-01 & 5.5E-05 & 9.7E-04 & 5.516E-05 \\
\hline 11 & DQ984827 & 1.0E-01 & 3.6E-01 & 2.3E-01 & 5.9E-01 & 2.6E-02 & 1.4E-01 & 2.1E-05 & 4.0E-04 & 2.073E-05 \\
\hline 12 & DQ451555 & 8.3E-02 & 3.1E-01 & 2.0E-01 & 5.5E-01 & 1.9E-02 & 1.1E-01 & 7.8E-06 & 1.6E-04 & 7.790E-06 \\
\hline 13 & DQ489377 & 6.7E-02 & 2.7E-01 & 1.8E-01 & 5.0E-01 & 1.4E-02 & 8.3E-02 & 2.9E-06 & 6.6E-05 & 2.927E-06 \\
\hline 14 & EF034085 & 5.5E-02 & 2.3E-01 & 1.5E-01 & 4.6E-01 & 9.9E-03 & 6.4E-02 & 1.1E-06 & 2.7E-05 & 1.100E-06 \\
\hline 15 & AY937242 & 4.5E-02 & 2.0E-01 & 1.4E-01 & 4.3E-01 & 7.1E-03 & 4.9E-02 & 4.1E-07 & 1.1E-05 & 4.144E-07 \\
\hline 16 & DQ846695 & 3.6E-02 & 1.7E-01 & 1.2E-01 & 3.9E-01 & 5.1E-03 & 3.7E-02 & 1.6E-07 & 4.3E-06 & $1.561 \mathrm{E}-07$ \\
\hline 17 & DQ888312 & 2.9E-02 & 1.4E-01 & 1.0E-01 & 3.6E-01 & 3.7E-03 & 2.8E-02 & 5.9E-08 & 1.7E-06 & 5.882E-08 \\
\hline 18 & AY856094 & 2.4E-02 & 1.2E-01 & 9.2E-02 & 3.3E-01 & 2.6E-03 & 2.1E-02 & 2.2E-08 & 6.9E-07 & 2.217E-08 \\
\hline 19 & AY853303 & 2.0E-02 & 1.0E-01 & 8.0E-02 & 3.0E-01 & 1.9E-03 & 1.6E-02 & 8.4E-09 & 2.7E-07 & 8.383E-09 \\
\hline 20 & DQ888310 & 1.6E-02 & 8.9E-02 & 7.1E-02 & 2.7E-01 & 1.4E-03 & 1.2E-02 & 3.2E-09 & 1.1E-07 & 3.170E-09 \\
\hline 21 & EF042090 & 1.3E-02 & 7.5E-02 & 6.2E-02 & $2.5 \mathrm{E}-01$ & 9.9E-04 & $9.1 \mathrm{E}-03$ & 1.2E-09 & 4.3E-08 & 1.199E-09 \\
\hline 22 & AY844963 & 1.1E-02 & 6.4E-02 & 5.4E-02 & 2.2E-01 & 7.1E-04 & 6.8E-03 & $4.5 \mathrm{E}-10$ & 1.7E-08 & $4.533 \mathrm{E}-10$ \\
\hline
\end{tabular}




\begin{tabular}{|c|c|c|c|c|c|c|c|c|c|}
\hline DQ846694 & 8.6E-03 & 5.4E-02 & 4.8E-02 & 2.0E-01 & 5.1E-04 & 5.1E-03 & $1.7 \mathrm{E}-10$ & 6.7E-09 & $1.714 \mathrm{E}-10$ \\
\hline DQ990835 & 7.0E-03 & 4.5E-02 & 4.2E-02 & $1.8 \mathrm{E}-01$ & 3.7E-04 & $3.8 \mathrm{E}-03$ & $6.5 \mathrm{E}-11$ & 2.6E-09 & $6.481 \mathrm{E}-11$ \\
\hline EF150946 & 5.7E-03 & 3.8E-02 & 3.7E-02 & 1.7E-01 & 2.7E-04 & $2.9 \mathrm{E}-03$ & $2.5 \mathrm{E}-11$ & 1.0E-09 & $2.451 \mathrm{E}-11$ \\
\hline AY851163 & 4.6E-03 & 3.2E-02 & 3.2E-02 & 1.5E-01 & 1.9E-04 & 2.1E-03 & $9.3 E-12$ & $4.1 \mathrm{E}-10$ & $9.312 \mathrm{E}-12$ \\
\hline AY929334 & $3.8 \mathrm{E}-03$ & 2.7E-02 & 2.9E-02 & $1.4 \mathrm{E}-01$ & 1.4E-04 & 1.6E-03 & $3.5 \mathrm{E}-12$ & $1.6 \mathrm{E}-10$ & $3.538 \mathrm{E}-12$ \\
\hline DQ990833 & $3.1 \mathrm{E}-03$ & 2.3E-02 & $2.5 \mathrm{E}-02$ & $1.2 \mathrm{E}-01$ & 1.0E-04 & $1.2 \mathrm{E}-03$ & 1.3E-12 & $6.4 \mathrm{E}-11$ & $1.344 \mathrm{E}-12$ \\
\hline AY851162 & $2.5 \mathrm{E}-03$ & 1.9E-02 & 2.2E-02 & 1.1E-01 & 7.3E-05 & 8.9E-04 & $5.1 \mathrm{E}-13$ & $2.5 \mathrm{E}-11$ & $5.108 \mathrm{E}-13$ \\
\hline DQ381153 & 2.0E-03 & 1.6E-02 & 1.9E-02 & 1.0E-01 & $5.2 \mathrm{E}-05$ & 6.6E-04 & $1.9 \mathrm{E}-13$ & $9.8 \mathrm{E}-12$ & $1.942 \mathrm{E}-13$ \\
\hline DQ674265 & 1.7E-03 & 1.3E-02 & 1.7E-02 & $9.1 \mathrm{E}-02$ & $3.8 \mathrm{E}-05$ & 4.9E-04 & $7.4 \mathrm{E}-14$ & $3.9 \mathrm{E}-12$ & $7.386 \mathrm{E}-14$ \\
\hline AY776154 & $1.4 \mathrm{E}-03$ & 1.1E-02 & 1.5E-02 & 8.3E-02 & 2.7E-05 & 3.7E-04 & $2.8 \mathrm{E}-14$ & $1.5 \mathrm{E}-12$ & $2.823 E-14$ \\
\hline AY858890 & 1.1E-03 & $9.5 \mathrm{E}-03$ & 1.3E-02 & 7.5E-02 & 2.0E-05 & 2.7E-04 & $1.1 \mathrm{E}-14$ & $6.0 \mathrm{E}-13$ & $1.079 \mathrm{E}-14$ \\
\hline DQ500958 & 9.0E-04 & 7.9E-03 & $1.2 \mathrm{E}-02$ & 6.7E-02 & $1.4 \mathrm{E}-05$ & 2.0E-04 & $4.1 \mathrm{E}-15$ & $2.4 \mathrm{E}-13$ & $4.125 \mathrm{E}-15$ \\
\hline DQ647188 & 7.4E-04 & 6.6E-03 & 1.0E-02 & 6.1E-02 & 1.0E-05 & 1.5E-04 & $<4.1 \mathrm{E}-15$ & $9.2 \mathrm{E}-14$ & $1.577 \mathrm{E}-15$ \\
\hline DQ837645 & $6.0 \mathrm{E}-04$ & 5.6E-03 & 9.1E-03 & 5.5E-02 & 7.5E-06 & $1.1 \mathrm{E}-04$ & & $3.6 \mathrm{E}-14$ & $6.027 \mathrm{E}-16$ \\
\hline DQ916058 & 4.9E-04 & 4.6E-03 & 8.0E-03 & 4.9E-02 & 5.4E-06 & 8.3E-05 & & $1.4 \mathrm{E}-14$ & $2.304 \mathrm{E}-16$ \\
\hline EF028073 & 4.0E-04 & $3.9 \mathrm{E}-03$ & 7.1E-03 & 4.5E-02 & $3.9 \mathrm{E}-06$ & $6.2 \mathrm{E}-05$ & & $5.6 \mathrm{E}-15$ & $8.815 \mathrm{E}-17$ \\
\hline DQ647190 & 3.3E-04 & $3.2 \mathrm{E}-03$ & 6.3E-03 & 4.0E-02 & 2.8E-06 & 4.6E-05 & & 2.2E-15 & $3.394 \mathrm{E}-17$ \\
\hline AY850194 & 2.7E-04 & 2.7E-03 & 5.5E-03 & 3.6E-02 & 2.1E-06 & $3.4 \mathrm{E}-05$ & & $<2.2 \mathrm{E}-15$ & $1.307 \mathrm{E}-17$ \\
\hline EF034080 & $2.2 \mathrm{E}-04$ & 2.3E-03 & 4.9E-03 & 3.3E-02 & 1.5E-06 & $2.5 \mathrm{E}-05$ & & & $5.030 \mathrm{E}-18$ \\
\hline DQ846692 & $1.8 \mathrm{E}-04$ & 1.9E-03 & 4.3E-03 & 3.0E-02 & $1.1 \mathrm{E}-06$ & 1.9E-05 & & & $1.940 \mathrm{E}-18$ \\
\hline DQ888313 & $1.5 \mathrm{E}-04$ & 1.6E-03 & $3.8 \mathrm{E}-03$ & 2.7E-02 & 7.8E-07 & $1.4 \mathrm{E}-05$ & & & $7.531 \mathrm{E}-19$ \\
\hline EF034082 & $1.2 \mathrm{E}-04$ & 1.3E-03 & $3.4 \mathrm{E}-03$ & 2.4E-02 & 5.7E-07 & 1.0E-05 & & & $2.924 \mathrm{E}-19$ \\
\hline DQ786762 & $9.8 \mathrm{E}-05$ & 1.1E-03 & 3.0E-03 & 2.2E-02 & 4.1E-07 & 7.6E-06 & & & $1.138 \mathrm{E}-19$ \\
\hline EF093509 & 8.1E-05 & 9.2E-04 & 2.7E-03 & 2.0E-02 & 3.0E-07 & 5.6E-06 & & & $4.426 \mathrm{E}-20$ \\
\hline AY853302 & 6.6E-05 & 7.7E-04 & $2.4 \mathrm{E}-03$ & $1.8 \mathrm{E}-02$ & 2.2E-07 & 4.2E-06 & & & $1.736 \mathrm{E}-20$ \\
\hline DQ786763 & 5.4E-05 & $6.5 \mathrm{E}-04$ & 2.1E-03 & 1.6E-02 & 1.6E-07 & 3.1E-06 & & & $6.805 E-21$ \\
\hline EF034083 & 4.5E-05 & 5.4E-04 & 1.9E-03 & 1.5E-02 & $1.2 \mathrm{E}-07$ & 2.3E-06 & & & $2.668 \mathrm{E}-21$ \\
\hline DQ650636 & 3.7E-05 & $4.5 \mathrm{E}-04$ & 1.7E-03 & 1.3E-02 & 8.5E-08 & 1.7E-06 & & & $1.049 \mathrm{E}-21$ \\
\hline DQ839235 & 3.0E-05 & 3.8E-04 & 1.5E-03 & $1.2 \mathrm{E}-02$ & $6.2 \mathrm{E}-08$ & 1.3E-06 & & & 4.124E-22 \\
\hline
\end{tabular}




\begin{tabular}{|c|c|c|c|c|c|c|c|c|}
\hline 52 & DQ846688 & $2.5 \mathrm{E}-05$ & $3.1 \mathrm{E}-04$ & $1.3 \mathrm{E}-03$ & $1.1 \mathrm{E}-02$ & $4.5 \mathrm{E}-08$ & $9.5 \mathrm{E}-07$ & 1.622E-22 \\
\hline 53 & DQ837644 & 2.0E-05 & $2.6 \mathrm{E}-04$ & $1.2 \mathrm{E}-03$ & $9.8 \mathrm{E}-03$ & 3.3E-08 & $7.0 \mathrm{E}-07$ & $6.376 \mathrm{E}-23$ \\
\hline 54 & DQ404153 & 1.7E-05 & 2.2E-04 & $1.1 \mathrm{E}-03$ & $8.9 \mathrm{E}-03$ & $2.4 \mathrm{E}-08$ & $5.2 \mathrm{E}-07$ & $2.528 \mathrm{E}-23$ \\
\hline 55 & EF026085 & $1.4 \mathrm{E}-05$ & $1.8 \mathrm{E}-04$ & $9.6 \mathrm{E}-04$ & $8.0 \mathrm{E}-03$ & $1.8 \mathrm{E}-08$ & $3.9 \mathrm{E}-07$ & $1.002 \mathrm{E}-23$ \\
\hline 56 & AY841151 & $1.1 \mathrm{E}-05$ & $1.5 \mathrm{E}-04$ & $8.5 \mathrm{E}-04$ & 7.3E-03 & $1.3 \mathrm{E}-08$ & $2.9 \mathrm{E}-07$ & $3.975 \mathrm{E}-24$ \\
\hline 57 & EF034081 & 9.3E-06 & $1.3 \mathrm{E}-04$ & $7.6 \mathrm{E}-04$ & $6.6 \mathrm{E}-03$ & $9.4 \mathrm{E}-09$ & 2.1E-07 & $1.576 \mathrm{E}-24$ \\
\hline 58 & DQ789028 & 7.6E-06 & $1.1 \mathrm{E}-04$ & $6.8 \mathrm{E}-04$ & $6.0 \mathrm{E}-03$ & $6.9 \mathrm{E}-09$ & $1.6 \mathrm{E}-07$ & $6.272 \mathrm{E}-25$ \\
\hline 59 & EF089234 & 6.3E-06 & $9.0 \mathrm{E}-05$ & $6.1 \mathrm{E}-04$ & $5.4 \mathrm{E}-03$ & $5.0 \mathrm{E}-09$ & $1.2 \mathrm{E}-07$ & $2.496 \mathrm{E}-25$ \\
\hline 60 & DQ422949 & $5.2 \mathrm{E}-06$ & 7.5E-05 & $5.5 \mathrm{E}-04$ & $4.9 \mathrm{E}-03$ & 3.7E-09 & $8.8 \mathrm{E}-08$ & $1.002 \mathrm{E}-25$ \\
\hline 61 & DQ485413 & 4.3E-06 & $6.3 \mathrm{E}-05$ & $4.9 \mathrm{E}-04$ & $4.5 \mathrm{E}-03$ & 2.7E-09 & $6.6 \mathrm{E}-08$ & $4.025 \mathrm{E}-26$ \\
\hline 62 & DQ435443 & $3.5 \mathrm{E}-06$ & 5.3E-05 & $4.4 \mathrm{E}-04$ & $4.1 \mathrm{E}-03$ & $2.0 \mathrm{E}-09$ & $4.9 \mathrm{E}-08$ & $1.616 \mathrm{E}-26$ \\
\hline 63 & DQ846690 & $2.9 \mathrm{E}-06$ & 4.4E-05 & $4.0 \mathrm{E}-04$ & 3.7E-03 & $1.5 \mathrm{E}-09$ & 3.7E-08 & $6.492 \mathrm{E}-27$ \\
\hline 64 & DQ888309 & 2.4E-06 & 3.7E-05 & 3.5E-04 & 3.4E-03 & $1.1 \mathrm{E}-09$ & 2.7E-08 & 2.607E-27 \\
\hline 65 & AY941204 & $2.0 \mathrm{E}-06$ & 3.1E-05 & $3.2 \mathrm{E}-04$ & $3.1 \mathrm{E}-03$ & $7.9 \mathrm{E}-10$ & 2.0E-08 & $1.062 \mathrm{E}-27$ \\
\hline 66 & DQ422950 & $1.6 \mathrm{E}-06$ & 2.6E-05 & $2.9 \mathrm{E}-04$ & $2.8 \mathrm{E}-03$ & $5.8 \mathrm{E}-10$ & $1.5 \mathrm{E}-08$ & $4.328 \mathrm{E}-28$ \\
\hline 67 & DQ786765 & $1.4 \mathrm{E}-06$ & 2.2E-05 & $2.6 \mathrm{E}-04$ & $2.5 \mathrm{E}-03$ & $4.3 \mathrm{E}-10$ & $1.1 \mathrm{E}-08$ & $1.763 \mathrm{E}-28$ \\
\hline 68 & EF093511 & $1.1 \mathrm{E}-06$ & $1.8 \mathrm{E}-05$ & 2.3E-04 & $2.3 \mathrm{E}-03$ & $3.2 \mathrm{E}-10$ & 8.5E-09 & 7.263E-29 \\
\hline 69 & DQ866817 & 9.3E-07 & $1.5 \mathrm{E}-05$ & $2.1 \mathrm{E}-04$ & $2.1 \mathrm{E}-03$ & $2.3 \mathrm{E}-10$ & 6.4E-09 & 3.007E-29 \\
\hline 70 & DQ990832 & 7.7E-07 & 1.3E-05 & $1.9 \mathrm{E}-04$ & $1.9 \mathrm{E}-03$ & $1.7 \mathrm{E}-10$ & $4.8 \mathrm{E}-09$ & $1.245 \mathrm{E}-29$ \\
\hline 71 & AY943841 & $6.4 \mathrm{E}-07$ & $1.1 \mathrm{E}-05$ & $1.7 \mathrm{E}-04$ & $1.8 \mathrm{E}-03$ & $1.3 \mathrm{E}-10$ & $3.6 \mathrm{E}-09$ & $5.186 \mathrm{E}-30$ \\
\hline 72 & DQ837646 & 5.3E-07 & $9.1 \mathrm{E}-06$ & $1.6 \mathrm{E}-04$ & $1.6 \mathrm{E}-03$ & $9.5 \mathrm{E}-11$ & 2.7E-09 & 2.161E-30 \\
\hline 73 & AY939849 & 4.4E-07 & 7.6E-06 & $1.4 \mathrm{E}-04$ & $1.5 \mathrm{E}-03$ & $7.1 \mathrm{E}-11$ & 2.0E-09 & $9.104 \mathrm{E}-31$ \\
\hline 74 & DQ995976 & 3.7E-07 & 6.4E-06 & $1.3 \mathrm{E}-04$ & $1.4 \mathrm{E}-03$ & $5.3 \mathrm{E}-11$ & 1.5E-09 & $3.836 \mathrm{E}-31$ \\
\hline 75 & DQ984825 & 3.1E-07 & 5.4E-06 & $1.2 \mathrm{E}-04$ & $1.3 \mathrm{E}-03$ & $3.9 \mathrm{E}-11$ & $1.1 \mathrm{E}-09$ & 1.629E-31 \\
\hline 76 & DQ786759 & 2.6E-07 & 4.6E-06 & $1.1 \mathrm{E}-04$ & $1.2 \mathrm{E}-03$ & $2.9 \mathrm{E}-11$ & 8.7E-10 & $7.000 \mathrm{E}-32$ \\
\hline 77 & EF026087 & 2.2E-07 & $3.9 \mathrm{E}-06$ & $1.0 \mathrm{E}-04$ & $1.1 \mathrm{E}-03$ & $2.2 \mathrm{E}-11$ & $6.5 \mathrm{E}-10$ & $3.008 \mathrm{E}-32$ \\
\hline 78 & DQ837643 & $1.8 \mathrm{E}-07$ & 3.3E-06 & $9.2 \mathrm{E}-05$ & $1.0 \mathrm{E}-03$ & $1.6 \mathrm{E}-11$ & $5.0 \mathrm{E}-10$ & 1.304E-32 \\
\hline 79 & AY842475 & $1.5 \mathrm{E}-07$ & $2.8 \mathrm{E}-06$ & 8.5E-05 & 9.3E-04 & $1.2 \mathrm{E}-11$ & $3.8 \mathrm{E}-10$ & 5.725E-33 \\
\hline 80 & DQ468384 & $1.3 \mathrm{E}-07$ & $2.4 \mathrm{E}-06$ & $7.9 \mathrm{E}-05$ & 8.7E-04 & $9.5 \mathrm{E}-12$ & $2.9 \mathrm{E}-10$ & $2.573 E-33$ \\
\hline
\end{tabular}




\begin{tabular}{|c|c|c|c|c|c|c|c|c|}
\hline 81 & DQ984826 & 1.1E-07 & 2.1E-06 & 7.4E-05 & 8.2E-04 & $7.2 \mathrm{E}-12$ & $2.2 \mathrm{E}-10$ & 1.186E-33 \\
\hline 82 & DQ404149 & 9.3E-08 & $1.8 \mathrm{E}-06$ & 6.8E-05 & 7.6E-04 & 5.5E-12 & 1.7E-10 & 5.466E-34 \\
\hline 83 & DQ786758 & 7.9E-08 & $1.5 \mathrm{E}-06$ & 6.4E-05 & $7.2 \mathrm{E}-04$ & $4.2 \mathrm{E}-12$ & $1.3 \mathrm{E}-10$ & $2.520 E-34$ \\
\hline 84 & DQ786766 & $6.8 \mathrm{E}-08$ & 1.3E-06 & 6.0E-05 & $6.8 \mathrm{E}-04$ & $3.2 \mathrm{E}-12$ & $1.0 \mathrm{E}-10$ & 1.194E-34 \\
\hline 85 & DQ984828 & 5.8E-08 & 1.1E-06 & 5.6E-05 & $6.4 \mathrm{E}-04$ & $2.5 \mathrm{E}-12$ & $8.0 \mathrm{E}-11$ & 5.655E-35 \\
\hline 86 & EF034086 & 4.9E-08 & $9.6 \mathrm{E}-07$ & 5.2E-05 & 6.0E-04 & $1.9 \mathrm{E}-12$ & $6.2 \mathrm{E}-11$ & 2.679E-35 \\
\hline 87 & DQ470475 & $4.2 \mathrm{E}-08$ & 8.3E-07 & 4.9E-05 & 5.6E-04 & $1.5 \mathrm{E}-12$ & $4.8 \mathrm{E}-11$ & $1.269 \mathrm{E}-35$ \\
\hline 88 & DQ647186 & 3.6E-08 & $7.2 \mathrm{E}-07$ & 4.6E-05 & 5.3E-04 & $1.1 \mathrm{E}-12$ & $3.8 \mathrm{E}-11$ & 6.107E-36 \\
\hline 89 & AY942198 & 3.1E-08 & $6.2 \mathrm{E}-07$ & 4.3E-05 & 5.0E-04 & 8.7E-13 & $2.9 \mathrm{E}-11$ & $2.980 E-36$ \\
\hline 90 & DQ846689 & 2.6E-08 & 5.4E-07 & 4.1E-05 & 4.8E-04 & $6.7 E-13$ & 2.3E-11 & $1.454 \mathrm{E}-36$ \\
\hline 91 & EF026084 & 2.3E-08 & 4.6E-07 & 3.8E-05 & $4.5 \mathrm{E}-04$ & $5.2 \mathrm{E}-13$ & $1.8 \mathrm{E}-11$ & 7.092E-37 \\
\hline 92 & DQ832700 & 2.0E-08 & 4.0E-07 & 3.6E-05 & 4.3E-04 & $4.1 \mathrm{E}-13$ & $1.4 \mathrm{E}-11$ & 3.460 E-37 \\
\hline 93 & AY919868 & 1.7E-08 & $3.5 \mathrm{E}-07$ & $3.4 \mathrm{E}-05$ & 4.1E-04 & $3.2 \mathrm{E}-13$ & $1.1 \mathrm{E}-11$ & 1.742E-37 \\
\hline 94 & DQ404150 & 1.5E-08 & 3.0E-07 & 3.2E-05 & 3.9E-04 & $2.5 E-13$ & 8.6E-12 & 8.772E-38 \\
\hline 95 & DQ990834 & 1.3E-08 & 2.6E-07 & 3.1E-05 & 3.7E-04 & $1.9 \mathrm{E}-13$ & $6.8 \mathrm{E}-12$ & 4.417E-38 \\
\hline 96 & EF026086 & 1.1E-08 & 2.3E-07 & 2.9E-05 & $3.5 \mathrm{E}-04$ & $1.5 \mathrm{E}-13$ & $5.4 \mathrm{E}-12$ & $2.268 E-38$ \\
\hline 97 & EF141102 & 9.4E-09 & 2.0E-07 & $2.8 \mathrm{E}-05$ & $3.4 \mathrm{E}-04$ & $1.2 \mathrm{E}-13$ & 4.3E-12 & 1.165E-38 \\
\hline 98 & EF093510 & 8.2E-09 & $1.8 \mathrm{E}-07$ & 2.6E-05 & $3.2 \mathrm{E}-04$ & $9.4 \mathrm{E}-14$ & $3.4 \mathrm{E}-12$ & 6.066E-39 \\
\hline 99 & DQ650635 & 7.2E-09 & $1.6 \mathrm{E}-07$ & $2.5 \mathrm{E}-05$ & 3.1E-04 & $7.5 \mathrm{E}-14$ & 2.7E-12 & 3.229E-39 \\
\hline 100 & DQ866818 & 6.3E-09 & $1.4 \mathrm{E}-07$ & 2.4E-05 & 3.0E-04 & $6.0 \mathrm{E}-14$ & $2.2 \mathrm{E}-12$ & $1.785 E-39$ \\
\hline 101 & AY842473 & 5.6E-09 & $1.2 \mathrm{E}-07$ & 2.3E-05 & $2.9 \mathrm{E}-04$ & $4.8 \mathrm{E}-14$ & $1.8 \mathrm{E}-12$ & $9.870 \mathrm{E}-40$ \\
\hline 102 & DQ995977 & 4.9E-09 & $1.1 \mathrm{E}-07$ & 2.3E-05 & $2.8 \mathrm{E}-04$ & $3.9 \mathrm{E}-14$ & $1.4 \mathrm{E}-12$ & $5.529 E-40$ \\
\hline 103 & DQ916059 & 4.4E-09 & 9.7E-08 & 2.2E-05 & 2.7E-04 & $3.1 \mathrm{E}-14$ & $1.2 \mathrm{E}-12$ & 3.097E-40 \\
\hline 104 & DQ647187 & 3.9E-09 & 8.7E-08 & 2.1E-05 & 2.6E-04 & $2.6 \mathrm{E}-14$ & 9.7E-13 & $1.805 \mathrm{E}-40$ \\
\hline 105 & DQ846691 & 3.5E-09 & $7.8 \mathrm{E}-08$ & 2.1E-05 & 2.6E-04 & $2.1 \mathrm{E}-14$ & 8.0E-13 & $1.096 \mathrm{E}-40$ \\
\hline 106 & AY761135 & 3.1E-09 & 7.1E-08 & 2.0E-05 & $2.5 \mathrm{E}-04$ & $1.8 \mathrm{E}-14$ & $6.6 \mathrm{E}-13$ & $6.660 \mathrm{E}-41$ \\
\hline 107 & AY849380 & 2.8E-09 & $6.4 \mathrm{E}-08$ & 1.9E-05 & $2.4 \mathrm{E}-04$ & $1.5 \mathrm{E}-14$ & $5.6 \mathrm{E}-13$ & 4.077E-41 \\
\hline 108 & DQ916057 & 2.6E-09 & 5.9E-08 & 1.9E-05 & 2.4E-04 & $1.2 \mathrm{E}-14$ & 4.7E-13 & $2.586 \mathrm{E}-41$ \\
\hline 109 & EF164803 & 2.3E-09 & 5.4E-08 & 1.9E-05 & 2.3E-04 & $1.0 \mathrm{E}-14$ & $4.0 \mathrm{E}-13$ & $1.716 \mathrm{E}-41$ \\
\hline
\end{tabular}




\begin{tabular}{lllllllll}
110 & DQ404151 & $2.2 \mathrm{E}-09$ & $4.9 \mathrm{E}-08$ & $1.8 \mathrm{E}-05$ & $2.3 \mathrm{E}-04$ & $8.9 \mathrm{E}-15$ & $3.5 \mathrm{E}-13$ & $1.138 \mathrm{E}-41$ \\
111 & DQ647189 & $2.0 \mathrm{E}-09$ & $4.6 \mathrm{E}-08$ & $1.8 \mathrm{E}-05$ & $2.3 \mathrm{E}-04$ & $7.7 \mathrm{E}-15$ & $3.0 \mathrm{E}-13$ & $7.838 \mathrm{E}-42$ \\
112 & DQ888311 & $1.8 \mathrm{E}-09$ & $4.3 \mathrm{E}-08$ & $1.8 \mathrm{E}-05$ & $2.3 \mathrm{E}-04$ & $6.7 \mathrm{E}-15$ & $2.6 \mathrm{E}-13$ & $5.449 \mathrm{E}-42$ \\
113 & EF034084 & $1.7 \mathrm{E}-09$ & $4.0 \mathrm{E}-08$ & $1.8 \mathrm{E}-05$ & $2.2 \mathrm{E}-04$ & $6.0 \mathrm{E}-15$ & $2.3 \mathrm{E}-13$ & $3.975 \mathrm{E}-42$ \\
114 & AY842472 & $1.7 \mathrm{E}-09$ & $3.9 \mathrm{E}-08$ & $1.8 \mathrm{E}-05$ & $2.2 \mathrm{E}-04$ & $5.6 \mathrm{E}-15$ & $2.2 \mathrm{E}-13$ & $3.047 \mathrm{E}-42$ \\
115 & EF034087 & $1.6 \mathrm{E}-09$ & $3.8 \mathrm{E}-08$ & $1.8 \mathrm{E}-05$ & $2.2 \mathrm{E}-04$ & $5.3 \mathrm{E}-15$ & $2.1 \mathrm{E}-13$ & $2.589 \mathrm{E}-42$ \\
116 & EF093512 & $1.4 \mathrm{E}-09$ & $3.2 \mathrm{E}-08$ & $1.6 \mathrm{E}-05$ & $2.1 \mathrm{E}-04$ & $4.0 \mathrm{E}-15$ & $1.6 \mathrm{E}-13$ & $2.450 \mathrm{E}-42$ \\
\hline
\end{tabular}


Table S6 Cumulative non-exclusion power (1 - Q) calculated for STR considering one and two mismatch criteria $\left(Q_{1}\right.$ and $\left.Q_{2}\right)$ in the following cases: two parents known, one parent known, missing parents, and matching samples. Match probability (MP) calculated for matching samples. Markers are listed in order of decreasing gene diversity $\left(h_{e}\right)$. Bold underlined when cumulative $1-Q$ reach to $1.0 \mathrm{E}-4(\mathrm{Q}=0.999)$

\begin{tabular}{|c|c|c|c|c|c|c|c|c|c|c|}
\hline \multirow{2}{*}{ Locus № } & \multirow{2}{*}{ STR } & \multicolumn{2}{|c|}{ two parents } & \multicolumn{2}{|c|}{ one parent } & \multicolumn{2}{|c|}{ Missing parents } & \multicolumn{2}{|c|}{ Match } & \multirow{2}{*}{ MP } \\
\hline & & $1-Q_{1}$ & $1-Q_{2}$ & 1- $Q_{1}$ & $1-Q_{2}$ & $1-Q_{1}$ & $1-Q_{2}$ & 1- $Q_{1}$ & $1-Q_{2}$ & \\
\hline 1 & ETH225 & 4.1E-01 & - & 5.9E-01 & - & 2.3E-01 & - & 8.0E-02 & - & 0.07297941 \\
\hline 2 & BM2113 & 1.7E-01 & $6.5 \mathrm{E}-01$ & $3.5 \mathrm{E}-01$ & 8.3E-01 & 5.1E-02 & 4.0E-01 & $6.0 \mathrm{E}-03$ & 1.4E-01 & 0.00551324 \\
\hline 3 & TGLA227 & 8.1E-02 & 4.0E-01 & 2.3E-01 & 6.7E-01 & 1.5E-02 & $1.5 \mathrm{E}-01$ & 6.0E-04 & 2.0E-02 & 0.00058243 \\
\hline 4 & TGLA126 & 3.9E-02 & 2.3E-01 & $1.5 \mathrm{E}-01$ & 5.2E-01 & 5.0E-03 & 5.7E-02 & 7.0E-05 & 3.0E-03 & 6.1679E-05 \\
\hline 5 & RM067 & 1.9E-02 & 1.4E-01 & 1.0E-01 & 4.0E-01 & 8.0E-04 & 2.1E-02 & 7.0E-06 & 4.0E-04 & 6.9633E-06 \\
\hline 6 & ETH3 & 1.1E-02 & 8.3E-02 & 7.2E-02 & 3.1E-01 & 6.0E-04 & $9.0 \mathrm{E}-03$ & 1.0E-06 & 6.0E-05 & 9.5781E-07 \\
\hline 7 & HAUT27 & 6.0E-03 & 5.1E-02 & 5.3E-02 & $2.5 \mathrm{E}-01$ & 2.0E-04 & 3.0E-03 & 2.0E-07 & $9.0 \mathrm{E}-06$ & 1.4179E-07 \\
\hline 8 & TGLA53 & 3.0E-03 & 3.1E-02 & 3.9E-02 & 2.0E-01 & 8.0E-05 & 2.0E-03 & 3.0E-08 & 2.0E-06 & 2.1429E-08 \\
\hline 9 & BRR & 2.0E-03 & $1.8 \mathrm{E}-02$ & 2.8E-02 & $1.5 \mathrm{E}-01$ & 3.0E-05 & 5.0E-04 & 3.0E-09 & 3.0E-07 & 2.8508E-09 \\
\hline 10 & INRA023 & 1.0E-03 & 1.1E-02 & 2.1E-02 & $1.2 \mathrm{E}-01$ & $9.0 \mathrm{E}-06$ & 3.0E-04 & $4.5 \mathrm{E}-10$ & 3.6E-08 & $4.5326 \mathrm{E}-10$ \\
\hline 11 & BM1824 & 6.0E-04 & 7.0E-03 & 1.6E-02 & $9.5 \mathrm{E}-02$ & 4.0E-06 & 1.0E-04 & $8.0 \mathrm{E}-11$ & 7.0E-09 & $7.8866 \mathrm{E}-11$ \\
\hline 12 & CSRM60 & 4.0E-04 & $5.0 \mathrm{E}-03$ & 1.3E-02 & 8.1E-02 & 2.0E-06 & 5.0E-05 & $8.0 \mathrm{E}-11$ & 7.0E-09 & $1.7891 \mathrm{E}-11$ \\
\hline 13 & ETH10 & 3.0E-04 & 3.0E-03 & 1.0E-02 & $6.8 \mathrm{E}-02$ & 8.0E-07 & 3.0E-05 & $4.0 \mathrm{E}-12$ & $4.0 \mathrm{E}-10$ & $3.8368 \mathrm{E}-12$ \\
\hline 14 & BM1818 & 2.0E-04 & 2.0E-03 & 9.0E-03 & 5.9E-02 & 5.0E-07 & 2.0E-05 & $1.0 \mathrm{E}-12$ & $1.0 \mathrm{E}-10$ & $9.9549 \mathrm{E}-13$ \\
\hline 15 & CSSM66 & 2.0E-04 & 2.0E-03 & 8.0E-03 & 5.3E-02 & 3.0E-07 & 9.0E-06 & $4.0 \mathrm{E}-13$ & $4.0 \mathrm{E}-11$ & $3.5866 \mathrm{E}-13$ \\
\hline 16 & TGLA122 & 1.0E-04 & 1.4E-03 & 7.0E-03 & 4.7E-02 & 2.0E-07 & 5.0E-06 & $1.0 \mathrm{E}-13$ & $2.0 \mathrm{E}-11$ & $9.3059 \mathrm{E}-14$ \\
\hline 17 & SPS115 & 7.0E-05 & 1.1E-03 & 6.1E-03 & 4.3E-02 & 1.0E-07 & 3.0E-06 & $1.0 \mathrm{E}-13$ & $4.0 \mathrm{E}-12$ & $3.2339 \mathrm{E}-14$ \\
\hline 18 & HEL1 & 6.0E-05 & 9.0E-04 & 5.9E-03 & 4.2E-02 & 1.0E-08 & 3.0E-06 & $3.0 \mathrm{E}-14$ & $3.0 \mathrm{E}-12$ & $1.8748 \mathrm{E}-14$ \\
\hline
\end{tabular}


Table S7 Match probability values obtained in recent studies of individual genetic traceability in cattle using microsatellites (short tandem repeats, STR) or single nucleotide polymorphism (up date form Dalvit et al., 2007 and Baldo et al., 2010)

\begin{tabular}{|c|c|c|c|}
\hline $\begin{array}{l}\text { Type and number } \\
\text { of markers }\end{array}$ & $\begin{array}{c}\text { Match } \\
\text { probability }\end{array}$ & Breeds & References \\
\hline SNP - 116 & $10^{-44}$ & Angus & Present work \\
\hline SNP - 50 & $10^{-22}$ & Angus & Present work \\
\hline SNP - 32 & $10^{-14}$ & Angus & Present work \\
\hline SNP - 25 & $10^{-11}$ & Angus & Present work \\
\hline STR - 18 & $10^{-14}$ & Angus & Present work \\
\hline STR - 12 & $10^{-12}$ & Angus & Present work \\
\hline SNP - 43 & $10^{-11}$ to $10^{-13}$ & $\begin{array}{l}\text { Limousin, Belgian Blue, Simmental, } \\
\text { Charolais, Aberdeen Angus, Holstein }\end{array}$ & Allen et al. (2010) \\
\hline STR - 11 & $10^{-9}$ & $\begin{array}{l}\text { Limousin, Belgian Blue, Simmental, } \\
\text { Charolais, Aberdeen Anqus, Holstein }\end{array}$ & Allen et al. (2010) \\
\hline STR - 11 & $10^{-8}$ to $10^{-11}$ & Angus & \multirow{4}{*}{$\begin{array}{l}\text { Baldo et al. (2010) } \\
\text { Hara et al. (2010b) } \\
\text { Hara et al. (2010a) } \\
\text { HapMap Consortium } \\
\text { (2009) }\end{array}$} \\
\hline SNP - 87 & $10^{-34}$ & Japanese black & \\
\hline SNP - 29 & $10^{-12}$ & Japanese black & \\
\hline SNP - 50 & $10^{-15}$ & Several breeds & \\
\hline SNP - 25 & $10^{-8}$ to $10^{-10}$ & $\begin{array}{l}\text { Holstein, Simmental, Limousin, Angus, } \\
\text { Charolais, Tux Cattle }\end{array}$ & Karniol et al. (2009) \\
\hline STR - 12 & $>1.4 \times 10^{-8}$ & $\begin{array}{l}\text { Piemontese, Chianina, Marchigiana, } \\
\text { Romagnola, Holstein Friesian, Brown } \\
\text { Swiss }\end{array}$ & Dalvit et al. (2008) \\
\hline SNP - 28 & \multirow{9}{*}{$\begin{array}{c}1.9 \times 10^{-11} \\
5 \times 10^{-6} \\
2.4 \times 10^{-8} \\
1.4 \times 10^{-13} \\
5.3 \times 10^{-11} \\
4.3 \times 10^{-8} \\
10^{-13}\end{array}$} & Angus, Hereford & $\begin{array}{l}\text { Van Eenennaam et al. } \\
(2007)\end{array}$ \\
\hline STR - 23 & & Angus, Hereford & $\begin{array}{l}\text { Van Eenennaam et al. } \\
\text { (2007) }\end{array}$ \\
\hline STR -12 & & \multirow{7}{*}{$\begin{array}{l}\text { Piemontese, Chianina, Marchigiana, } \\
\text { Romagnola } \\
\text { Simulated data } \\
\text { Galloway } \\
\text { Galloway } \\
\text { Galloway } \\
\text { Holstein Friesian, and others } \\
\text { Holstein, German Fleckvieh, German } \\
\text { Braunvieh }\end{array}$} & Dalvit et al. (2006) \\
\hline SNP - 25 & & & Weller et al. (2006) \\
\hline STR- 10 & & & Herraéz et al. (2005) \\
\hline STR -17 & & & Herraéz et al. (2005) \\
\hline$S N P-43$ & & & Herraéz et al. (2005) \\
\hline SNP - 20 & & & Heaton et al. (2005) \\
\hline SNP - 37 & & & Werner et al. (2004) \\
\hline SNP - 32 & $2.0 \times 10^{-13}$ & \multirow{4}{*}{$\begin{array}{l}\text { American Angus } \\
\text { multi-breed composite populations } \\
\text { Pirenaica } \\
\text { Piemontese, Chinina, Holstein Friesian, } \\
\text { Italian Simmental }\end{array}$} & Heaton et al. (2002) \\
\hline SNP - 32 & $1.9 \times 10^{-10}$ & & Heaton et al. (2002) \\
\hline STR - 10 & $>10^{-7}$ & & Arana et al. (2002) \\
\hline STR - 13 & $>10^{-15}$ & & Orrù et al. (2006) \\
\hline STR -11 & $5 \times 10^{-12}$ & Charolaise & $\begin{array}{l}\text { Sancristobal-Gaudy et } \\
\text { al. (2000) }\end{array}$ \\
\hline STR -10 & $1 \times 10^{-10}$ & Belgium beef cattle & Peelman et al. (1998) \\
\hline
\end{tabular}

